\title{
Jogos eletrônicos educativos de inglês como língua estrangeira: uma avaliação enquanto material didático
}

\author{
Luciana Braga Carneiro Leão-Junqueira \\ Fundação de Apoio à Escola Técnica (FAETEC)
}

\begin{abstract}
Resumo
Este trabalho analisa jogos eletrônicos educativos para o ensino de ILE indicados aos anos finais do ensino fundamental. Verifica-se se esses jogos alcançam a prática e uso efetivos do conteúdo linguístico a que se designam e segundo as correntes teóricas a que se propõem; se os mesmos se caracterizam como jogos e não meras reproduções digitais de exercícios; e se tais atividades estão de acordo com os parâmetros estabelecidos por documentos nacionais como a LDB (BRASIL, 1996), os PCNs-LE (BRASIL, 1998) e os Guias do PNLD (BRASIL, 2010; 2014).

Palavras-chave: Jogos educativos; Software educacional; Avaliação de material didático de LE.
\end{abstract}

\begin{abstract}
This paper analyzes educational games for the teaching of EFL for the final year of Brazilian 'ensino fundamental'. It examines several aspects of the games. One is whether those games provide effective practice and usage of the linguistic features for which they are meant and according to the theoretical views they claim to follow. The paper also considers whether they can be characterized as games instead of mere digital reproduction of exercises; and whether such activities are in concordance with the parameters established by Brazilian official documents such as LDB (BRASIL, 1996), PCNs-LE (BRASIL, 1998) and the guides for PNLD (BRASIL, 2010; 2014).
\end{abstract}

Keywords: Educational games, educational software, evaluation of EFL teaching material

\section{INTRODUÇÃ̃O}

Com o avanço das tecnologias e sua disseminação no uso cotidiano, tornam-se cada vez mais frequentes os materiais didáticos nos quais a tecnologia está presente em suas mais variadas formas. E, dentre esses, os jogos parecem ser dos que mais despertam interesse entre alunos e professores, seja pelo seu caráter lúdico, que aumentaria a motivação, seja pelo seu alto valor educativo no que diz respeito à organização do conhecimento e dos feedbacks que eles oferecem imediatamente ao aprendiz. 
Apesar dos jogos eletrônicos já terem sido comprovados como ferramentas que aprimoram o processo de ensino-aprendizagem de língua estrangeira - doravante LE (PRENSKY, 2001; LEÃO, 2014), a escolha dos mesmos é feita, muitas vezes, mais por uma empolgação tecnológica e pedagógica do que baseada numa avaliação concreta do grau real de contribuição que esse recurso trará (HAYS, 2005).

A falta de conhecimento sobre o que seria de fato um jogo educativo, faz com que atividades comuns sejam apresentadas como jogos, quando na verdade são apenas exercícios transferidos para o suporte digital. Muitas vezes falta aos desenvolvedores um conhecimento mais aprofundado sobre as teorias e metodologias de ensino de línguas, levando-os a apresentar atividades que não atingem de forma eficiente o desenvolvimento das habilidades linguísticas a que se destinam. Por outro lado, por vezes, falta também aos educadores um conhecimento mais aprofundado de tecnologias, o que leva à aquisição de softwares de baixa qualidade e difícil aplicação prática, o que faz com que, eventualmente, acabem deixados de lado (BERTOLDI, 1999).

O presente trabalho tem por objetivo apresentar os jogos eletrônicos educativos como uma forma de atividade didática, e que, por esta causa, devem ser desenvolvidos e analisados através das mesmas orientações que norteiem a avaliação de materiais didáticos. Para tal, buscaremos responder se: (a) apresentam características lúdicas que os definiriam como de fato pertencentes ao gênero jogo; (b) inserem-se em na proposta didáticopedagógica que indicam; (c) estão em consonância como o que determinam os documentos oficiais que regulam o ensino de inglês como língua estrangeira no Brasil; e (d) seriam aprovados pelas questões avaliadoras referentes a jogos apresentados em conteúdos multimídia do Edital PNLD 2014.

\section{ABORDAGENS TEÓRICAS}

Para que possamos melhor avaliar os conteúdos midiáticos que serão apresentados no corpus de análise, faz-se necessário, primeiramente, que abordemos alguns pressupostos teóricos que permeiam as áreas de softwares educacionais para o ensino de línguas, jogos e jogos educacionais, de regulamentação do ensino de inglês como língua estrangeira doravante ILE - no Brasil, e da avaliação de jogos eletrônicos desenvolvidos para o ensino-aprendizagem de ILE. 


\section{Jogos}

Os jogos são os tipos de softwares mais procurados pelas crianças e adolescentes que utilizam tecnologias (MORAIS, 2003). O intuito dos jogos educativos é o de fazer com que os alunos aprendam com prazer, aumentando seu conhecimento e seu uso criativo através da diversão. Um jogo pode possuir características diversas, mas quatro elementos são essenciais para definir uma atividade como tal: a brincadeira, as regras, o objetivo e o fazde-conta (ADAMS, 2010).

Os jogos eletrônicos são aqueles mediados por computadores, expandindo o entretenimento dos jogos convencionais, uma vez que apresentam a realidade de faz-deconta do jogo de maneira muito mais direta ao jogador. Dessa forma, os jogos eletrônicos proporcionam imersão, i.e., a sensação de estar submerso em uma forma de entretenimento, sem se preocupar em controlar as regras, que faz com que muitas vezes esqueçamos que se trata de um mundo artificial (idem).

Durante o aprendizado, receber feedback sobre seus erros é de extrema importância para o aprendiz, no entanto extremamente difícil de se dar de maneira apropriada (LYSTER \& RANTA, 2007). A exposição da falta de conhecimento ou incapacidade do aluno diminui sua motivação e aumenta seu bloqueio, e é principal motivo pelo qual os aprendizes não se interessam por atividades que apresentem feedbacks apenas através de frases como "resposta errada" ou "tente novamente". Os jogos eletrônicos apresentam formas criativas de indicar que o jogador não agiu da forma esperada. $\mathrm{O}$ erro não resulta em uma repreensão, mas sim em uma experiência divertida, que, ainda assim, indica que um erro foi cometido e deve ser revisto.

\section{Avaliação de jogos eletrônicos educativos para o ensino de inglês como língua estrangeira}

Para que se possa pensar em avaliação de jogos eletrônicos educativos para o ensino de ILE, e em especial no contexto brasileiro, três pontos deverão nortear esta análise. São eles os documentos oficiais brasileiros que regulam o ensino de ILE; as questões técnicas que envolvem a avaliação de um software educacional; e as questões para avaliação de conteúdo multimídia do Programa Nacional do Livro Didático - doravante PNLD. Tratamos desses pontos e apresentamos suas contribuições para a avaliação de jogos educacionais a seguir. 


\section{Documentos oficiais reguladores do ensino de línguas estrangeiras no Brasil}

Os PCNs (BRASIL, 1998) definem como objetivos do ensino fundamental que os alunos sejam capazes de saber utilizar diferentes fontes de informação e recursos tecnológicos para adquirir e construir conhecimentos. No entanto, a adoção de qualquer material didático deve ser feita de modo que o processo de ensino e aprendizagem desenvolvido a partir dele esteja nos moldes determinados por esse documento. No caso do ensino de LE, onde se inclui o ensino de ILE, estes são configurados por uma visão sociointeracional da linguagem e da aprendizagem. Esta visão prega a inclusão de atividades significativas em sala de aula, o que permitiria ampliar os vínculos afetivos, e conferir a realização de tarefas de forma mais prazerosa. Os objetivos de uma atividade devem levar em consideração, além das capacidades cognitivas do aluno, as suas questões afetivas. Assim, atividades motivadoras são de grande importância ao longo de todo o processo de aprendizagem (BRASIL, 1998).

Sobre o uso de tecnologias, os PCNs mencionam seu forte impacto na sociedade e o papel da aprendizagem de LE como meio de inserção do indivíduo nesse novo contexto social. O documento incentiva o uso de softwares para ensino de Língua Estrangeira, mas reitera que

(...) é necessário adotar uma atitude crítica ao examiná-los, a fim de certificar-se que não sejam meras reproduções de um tipo de instrução programada (...). Exercícios que não exijam o envolvimento discursivo do aluno são incompatíveis com a visão de linguagem e de aprendizagem de Língua Estrangeira apresentada nestes parâmetros. (BRASIL, 1998, p. 87)

\section{Questões técnicas de avaliação de software educacional}

Da mesma forma que não é qualquer livro didático que se encaixa nas necessidades de um grupo de alunos, nas propostas político-pedagógicas e metodologias adotadas na escola, ou mesmo que apresenta todos os conteúdos de forma coerente, atualizada e sem erros, o mesmo se pode dizer de um software educacional. A seleção de um software representa uma atitude de base didático-pedagógica e de percepção do cotidiano institucional de ensino-aprendizagem (SILVA, 2009).

Bertoldi (2009) alerta que, muitas vezes, o despreparo de alguns educadores com a área tecnológica impossibilita a avaliação satisfatória dos softwares educacionais disponíveis. Em consequência disto, programas que não possuem boa aplicação didática são adquiridos e, por sua baixa qualidade, não são utilizados, tornando a aquisição de material e equipamento um desperdício de verbas e tempo. Com relação aos critérios 
técnicos a serem considerados, Morais (2003) indica questões relacionadas à (1) facilidade de uso; (2) programação; (3) legibilidade; (4) alterabilidade; (5) operacionalidade; e (6) documentação.

\section{Edital PNLD 2014 e questões para a avaliação de conteúdo multimídia}

O Guia PNLD 2014 (BRASIL, 2013), pela primeira vez, teve a intenção de disponibilizar obras acompanhadas de softwares educacionais dentre essas opções. No seu Edital (BRASIL, 2012) foram apresentados critérios eliminatórios comuns a todas as áreas, específicos de cada disciplina, e específicos para os conteúdos multimídia. Dentre os critérios comuns a todas as áreas, se destacam o que diz respeito (1) à legislação, às diretrizes e às normas oficiais relativas à educação básica; (2) à observância de princípios éticos necessários à construção da cidadania e ao convívio social; (3) à coerência e adequação da abordagem teórico-metodológica assumida pela coleção; (4) à correção e atualização de conceitos, informações e procedimentos; e (5) à organização clara, coerente e funcional, com legibilidade gráfica, ilustrações adequadas às finalidades para as quais foram elaboradas.

Dentre questões específicas à LE, destacamos: (1) reunir um conjunto de textos verbais, não verbais e verbo-visuais, representativos das comunidades falantes da língua estrangeira, com temas adequados aos anos finais do ensino fundamental, e que não veicule estereótipos nem preconceitos em relação às culturas estrangeiras envolvidas, nem à brasileira; (2) favorecer o acesso à diversidade cultural, social, étnica, etária e de gênero manifestada na língua estrangeira; (3) permitir o acesso a diferentes pronúncias e prosódias, propondo a sistematização de conhecimentos linguísticos, a partir do estudo de situações contextualizadas de uso da língua estrangeira; e (4) articular o estudo da língua estrangeira e manifestações que valorizam as relações de afeto e de respeito mútuo.

O documento apresenta, ainda, especificações técnicas a respeito dos conteúdos multimídia. Dentre essas especificações, todos devem (1) estar formatados em uma estrutura específica, com menu de navegação com iniciação automática que seja autoexplicativo; (2) possuir submenus, tutoriais e guias e que tenham navegação própria e independente dos demais objetos e conteúdos; (3) apresentar menu de navegação que proporcione acessibilidade aos portadores de deficiência; (4) funcionar perfeitamente nos principais sistemas operacionais; (5) apresentar objetivos educacionais bem definidos e clareza nas competências a serem desenvolvidas pelos estudantes; e (6) apresentar temas 
atraentes e adequados ao público alvo. Sobre jogos eletrônicos educativos, o Edital indica, ainda, que as atividades devem ser destinadas à comprovação de hipóteses, resolução de problemas, relacionamento dos conceitos, e testagem de diferentes caminhos; de forma que o usuário consiga chegar, por meio de uma estratégia de jogo, às conclusões conceituais relativas à proposta curricular da coleção.

\section{AVALIAÇÃO DO CORPUS}

Apresentamos, a seguir, três jogos selecionados para avaliação. O primeiro jogo se encontra em um site de materiais para a aprendizagem de ILE (MANY THINGS, 1997), numa sessão de jogos e quizzes. Já o segundo jogo integra um site que se classifica como um curso online baseado em jogos (INGLÊS ONLINE, 2013). Por fim, o terceiro jogo do corpus está hospedado em um site de jogos (UOL, 2013), na subseção de jogos de ILE de sua seção de jogos educativos. Os três foram definidos como jogos pelos seus desenvolvedores e trabalham conteúdos comuns ao início da aprendizagem de ILE como números, cores e vocabulário básico do dia-a-dia. Além disso, todos foram desenvolvidos almejando como público alvo crianças na faixa etária entre 10 e 15 anos, o que corresponde ao ensino fundamental brasileiro. Até o presente momento, os jogos aqui analisados encontram-se disponíveis gratuitamente em seus respectivos sites.

\section{Jogo 1}

\section{Adjectives}

Click the correct picture. You can use the RETURN key to close the alert window.

1. warm

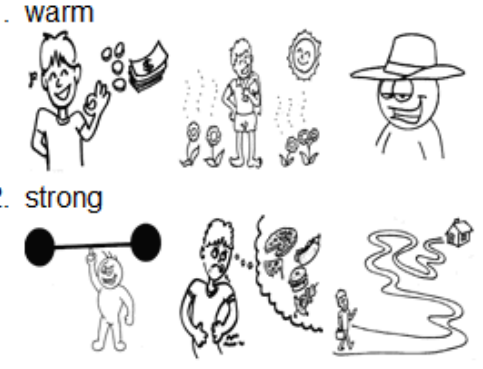

3. slow

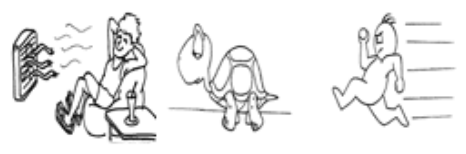

Figura 1 - apresentação inicial do jogo (MANY THINGS, 1997) 
O primeiro jogo a ser avaliado trabalha adjetivos comumente utilizados no dia-a-dia. Quanto aos aspectos técnicos, percebe-se que nenhuma página inicial introduz o jogo ou indica seus objetivos didáticos e metodológicos. Há apenas um menu pelo qual se seleciona o tópico linguístico que o aprendiz queira praticar dentre os disponíveis, e o enunciado da atividade. A apresentação gráfica é pobre, com um fundo branco, o texto em preto e as imagens em preto e branco.

A facilidade de uso e operacionalidade do software estão presentes, porém, não por uma programação que dê conta desses quesitos, mas pelo seu caráter simplório. A atividade é desenvolvida sem grandes recursos visuais e nenhum sonoro. A legibilidade é boa, porém, novamente, a mesma é facilitada devido à falta de cores ou estruturação gráfica complexa. O mesmo pode se dizer da clareza de instruções, que são compreensíveis aos alunos iniciantes, mas muito disso se dá por ser uma atividade simples e que só apresenta texto em uma única frase do enunciado. Ainda, não há possibilidade de alterações ou melhorias para a atividade, uma vez que não há outras informações ou locais em todo o software além das páginas de atividades, impossibilitando o contato entre desenvolvedores e usuários.

No que diz respeito às questões educacionais, trata-se de uma atividade formalista $\mathrm{e}$ descontextualizada. $\mathrm{O}$ aluno deve apenas indicar qual a figura que melhor representa $\mathrm{o}$ vocábulo, demonstrando, assim, conhecimento lexical do mesmo. Mais além, cada item testado é dispare do outro. Por exemplo, no item 1, questiona-se o vocábulo warm (morno), enquanto no item 2 temos strong (forte) e no terceiro slow (lento), o que não desenvolve um conhecimento sistemático e esquemático, dificultando a apreensão do léxico. Não apresenta, portanto, uma abordagem sociointeracional. Assim sendo, utiliza procedimentos desatualizados e incoerentes com os documentos nacionais. Além disso, o aluno não é capacitado a desenvolver consciência linguística e crítica dos usos que se fazem em diferentes contextos sociais, regionais, e interacionais.

O feedback às respostas selecionadas pelo aluno é dado através de caixas de texto simples que se sobressaem ao exercício, e indicam, no momento do clique, se a resposta dada a cada item está certa ou errada e a porcentagem de acertos até aquele momento. Representa-se, dessa forma, a noção de conhecimento mensurado apenas quantitativamente, numa visão binária de certo-errado, no lugar de um conhecimento construído gradualmente. Destaca-se ainda a maneira agressiva com que o feedback é dado, através apenas das palavras correct (certo) e wrong (errado) apresentadas em letra 
maiúscula e seguidas de uma exclamação, ambos elementos tipográficos que representam um discurso enfático, ou um tom de voz mais alto.

\section{Adjectives}

Click the correct picture. You can use the RETURN key to close the alert window.

1. warm

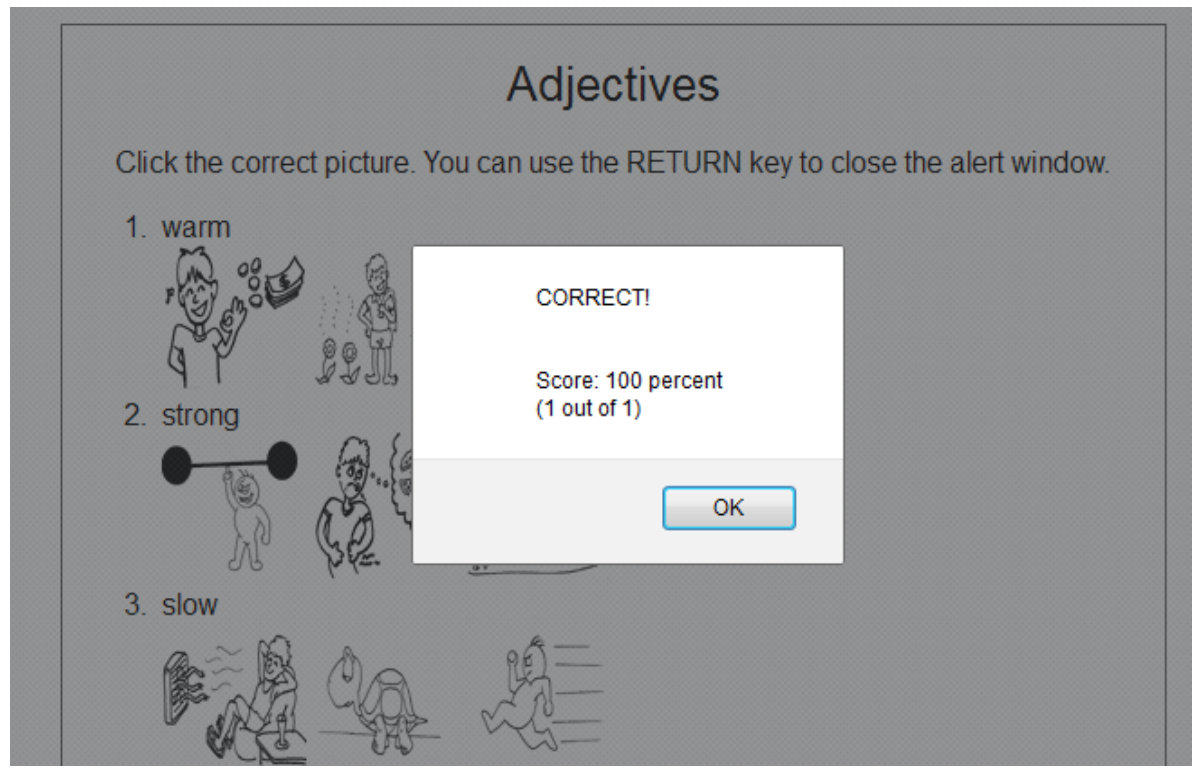

Figura 2 - Feedback positivo (MANY THINGS, 1997)

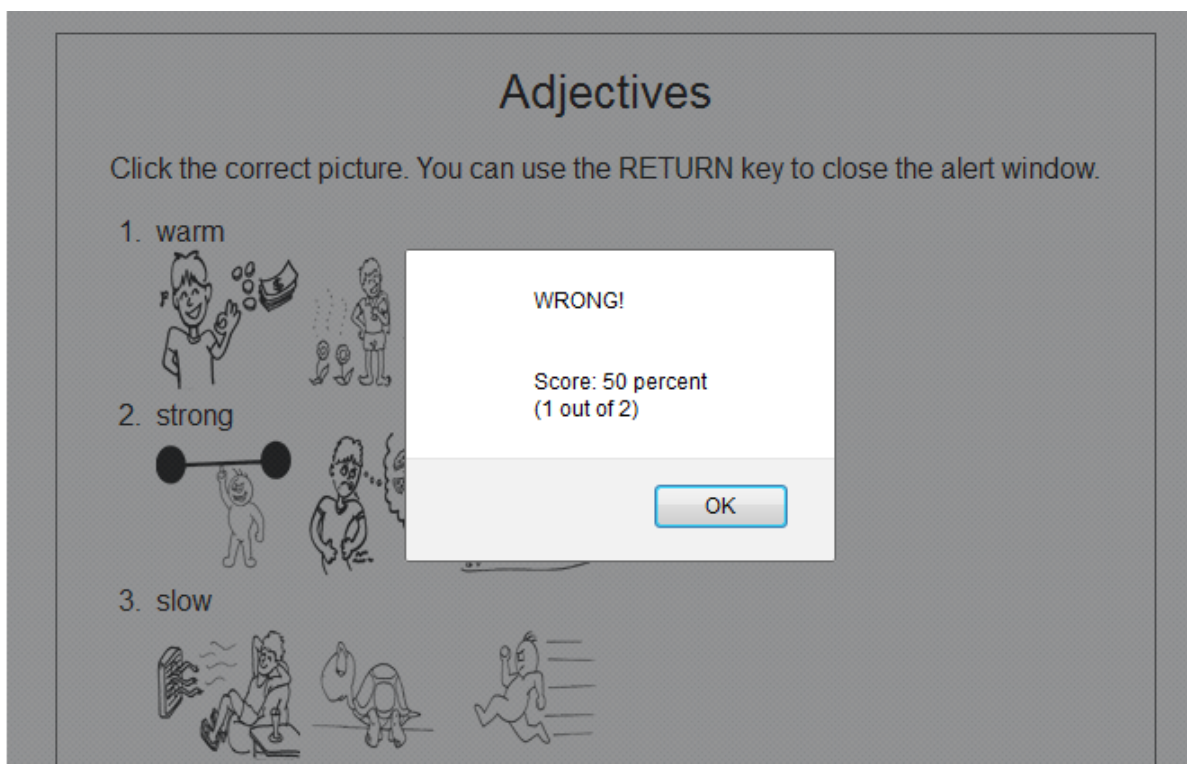

Figura 3 - Feedback negativo (MANY THINGS, 1997)

Caso o aluno selecione a opção errada, é negado ao aluno a possibilidade de tentar novamente. Esse impedimento, além de antididático, por negar ao aluno um processo de descoberta que talvez levasse até a um aprendizado mais sólido e revocável, impossibilita 
ao aluno o aprendizado daquele item lexical, uma vez que não the é informado nesse momento, ou ao final da atividade, qual seria a resposta correta.

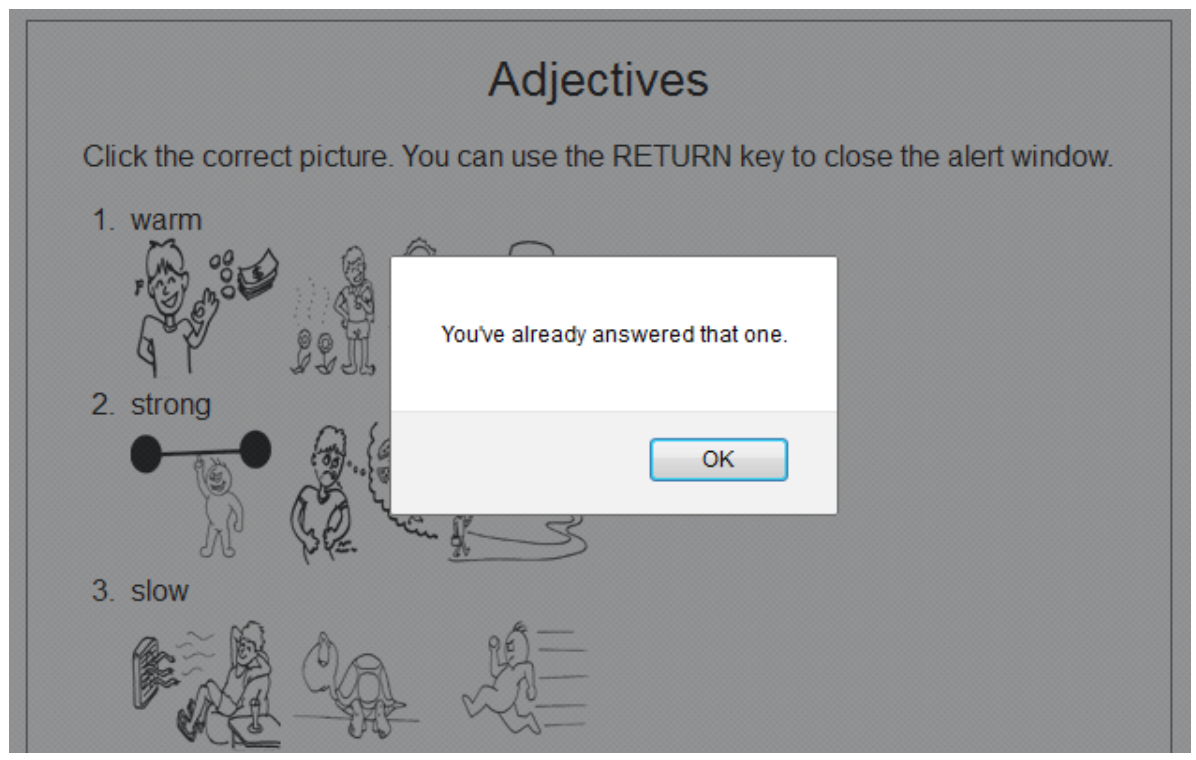

Figura 4 - Rejogabilidade (MANY THINGS, 1997)

Ao final da lista de itens é dado apenas o percentual final de acertos. Não há nada que indique o término da atividade, demonstrando que o aprendiz foi capaz de concluí-la. Não há recompensa pela finalização da atividade, indicação do cumprimento de objetivos ou um feedback mais completo que analise o resultado obtido pelo aluno.

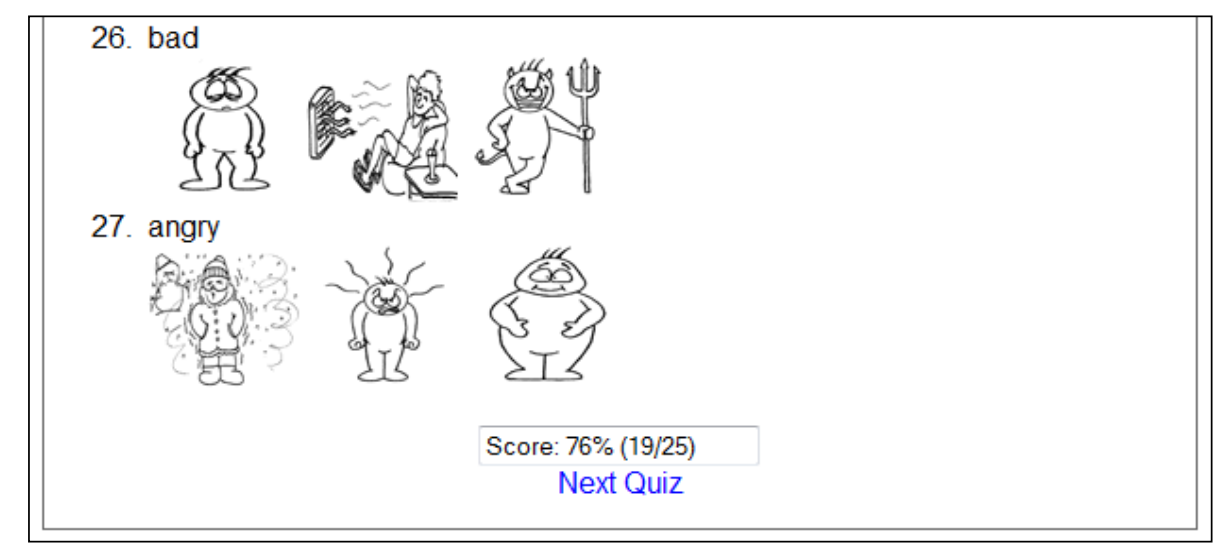

Figura 5 - Resultado final (MANY THINGS, 1997)

A atividade não traz nenhum caráter que a diferencie de um exercício de fixação de vocabulário que poderia estar impresso em um livro didático ou ser trazido como exercício 
extra pelo professor. Não há nela caráter multimídia, tratando-se apenas de uma mudança de suporte, perdendo a motivação despertada pelo fator tecnológico. Mais além, uma atividade dessas depende diretamente de uma instrução formal e apresentação de vocabulário prévias, pois, caso o aluno não acerte de primeira a resposta de cada item, ficará sem saber a resposta correta. Assim sendo, não é possível ao aluno a feitura autônoma e fora do ambiente escolar.

Outra característica da atividade é a inobservância de princípios éticos necessários à construção da cidadania e ao convívio social. Conforme podemos observar nas imagens abaixo, os desenhos que representam os vocábulos rich (rico) e poor (pobre) demonstram respectivamente um menino feliz e outro triste, levando à insinuação de que o dinheiro é fator condicionante da felicidade. Além disso, percebe-se que o menino representando "pobre" está sujo e maltrapilho, como se o dinheiro condicionasse também a higiene pessoal e roupas asseadas.

Já na representação do adjetivo old (velho), temos um senhor idoso com dores e dificuldade de andar. Essa representação estimula o estereótipo de idade avançada, e o uso grosseiro do vocábulo 'velho' para defini-lo. A representação desse vocábulo poderia ser feita com um objeto já gasto pelo tempo e uso, em quanto a representação referente à idade poderia ser feita através do vocábulo elderly (idoso) e uma imagem de um senhor(a) feliz, com boa aparência e disposição física. O mesmo se dá com a representação do vocábulo fat (gordo), também politicamente incorreto e rude. Uma melhor escolha para se descrever uma pessoa acima do peso em língua inglesa seria o vocábulo heavy, cujo uso na língua inglesa implica uma forma menos agressiva e estereotipada.

Outro exemplo é o relativo ao adjetivo paintful (doloroso). A imagem utilizada para representar a ideia de dor traz uma personagem sendo agredida, com o arremesso de uma pedra em sua cabeça pelas costas. A imagem estimula a violência e falta de respeito entre colegas e pode até incitar alunos a simularem a cena. Outras formas de se representar a dor poderiam ter sido utilizadas, como um machucado, sem demonstrar o que o ocasionou. 


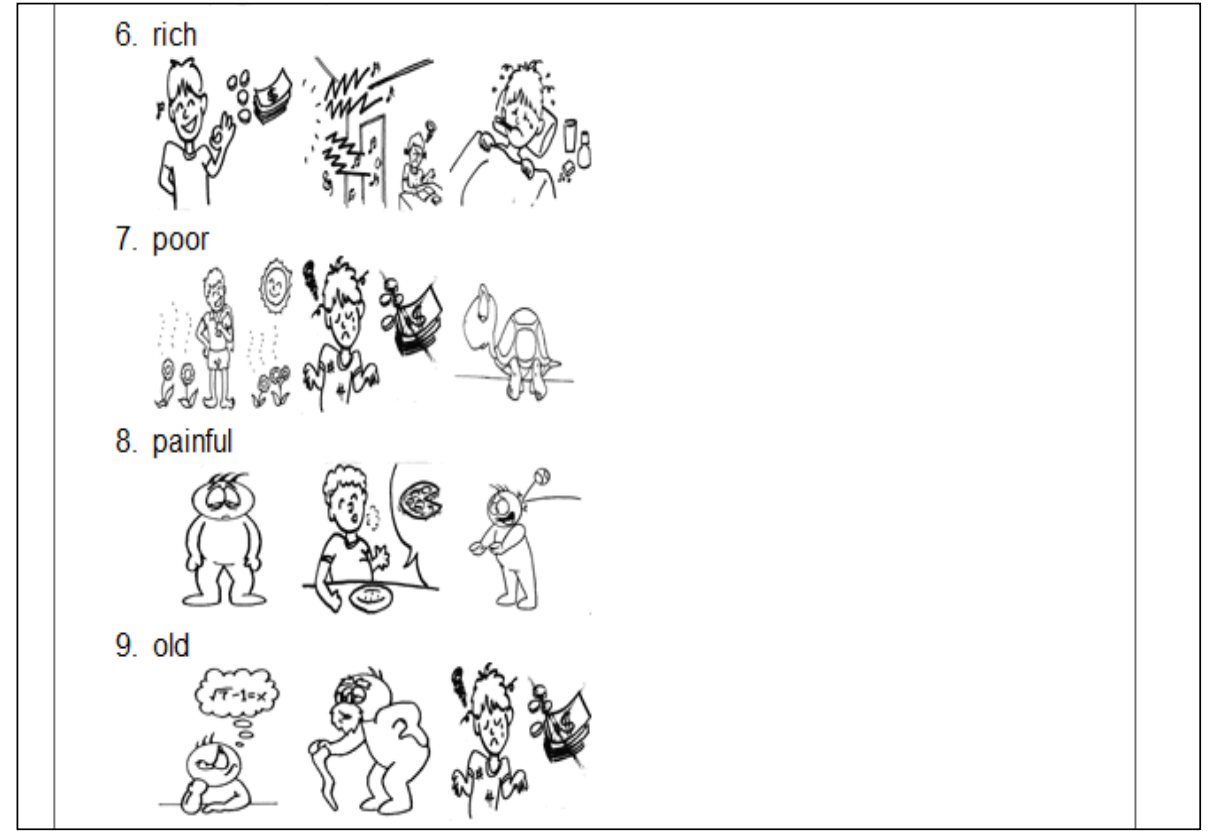

Figura 6-Representações de 'rico', 'pobre', 'doloroso' e 'velho' (MANY THINGS, 1997)

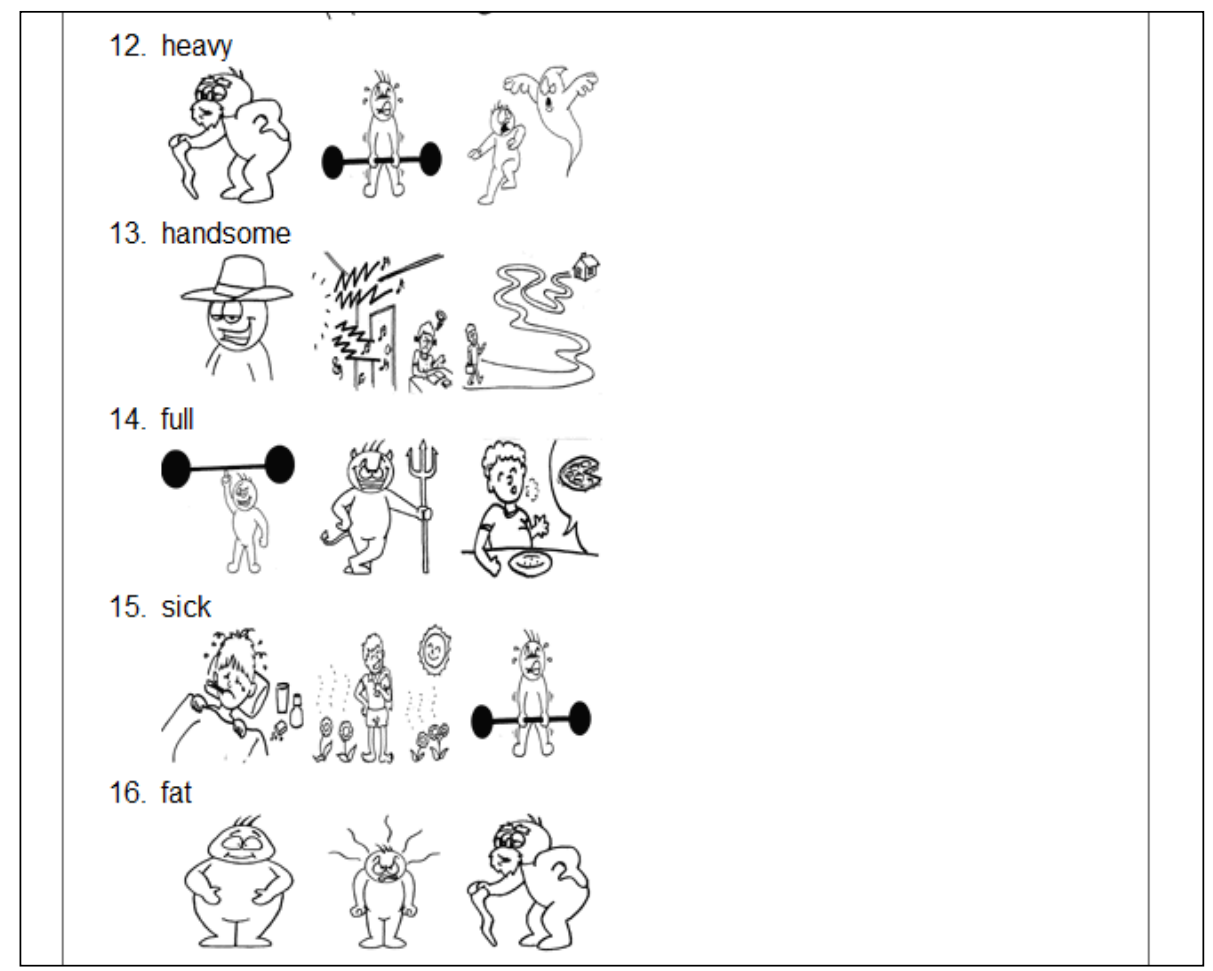

Figura 7-Representação de 'gordo' (MANY THINGS, 1997)

Finalmente, a atividade de software educacional apresentada acima não se trata de um jogo educativo, apesar de o ser denominado pelos seus desenvolvedores. Na verdade, trata-se de exercício voltado para o desenvolvimento de habilidades específicas, por meio 
de repetição, associação simples e memorização. E mesmo como exercício não seria uma boa opção, por todos os fatores apresentados anteriormente.

\section{Jogo 2}

O segundo jogo avaliado já apresenta um layout melhor desenvolvido e é estruturado em uma programação mais complexa. O software apresenta recursos de estruturação em níveis de conhecimento e tópicos linguísticos sistematizados que facilitam tanto a navegabilidade quanto para que se desenvolva um conhecimento esquemático dos itens trabalhados.

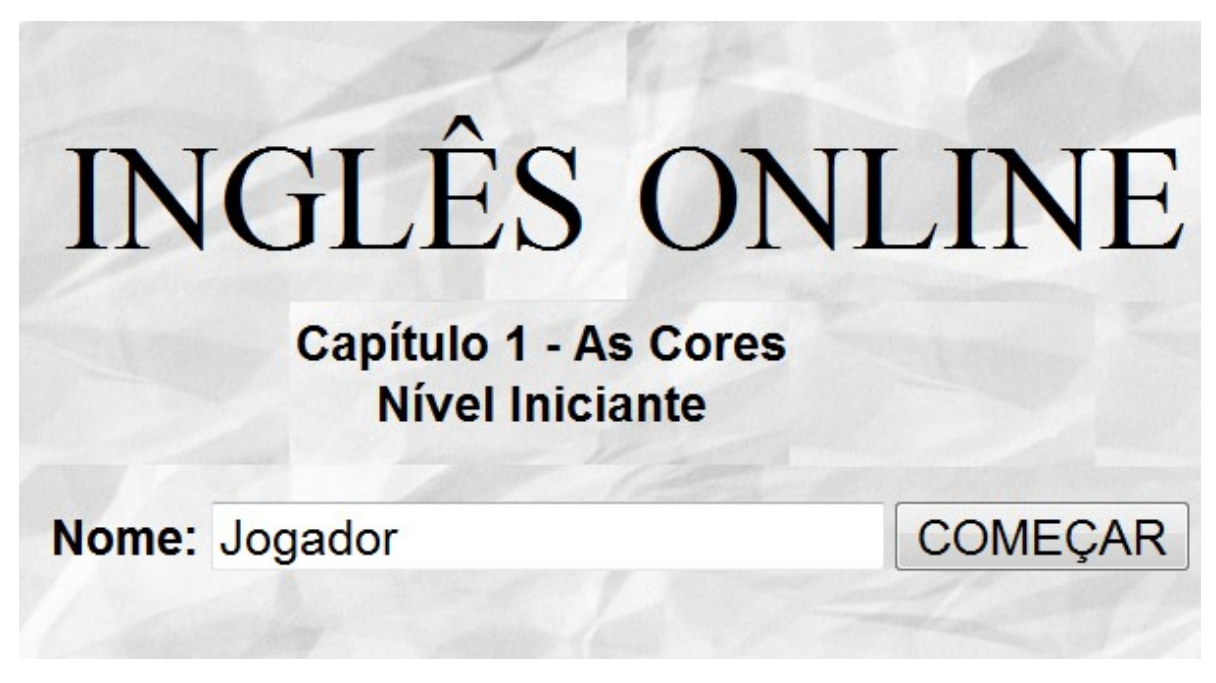

Figura 8-Apresentação inicial (INGLÊS ONLINE, 2013)

Ainda assim, a atividade é simples: ao trabalhar as cores, é apresentado o nome de determinada cor e se pede apenas que o jogador clique em cima do quadrado correspondente. Apesar de significativa, não é sociointeracional, uma vez que não está usando esse conteúdo linguístico de maneira contextualizada. 


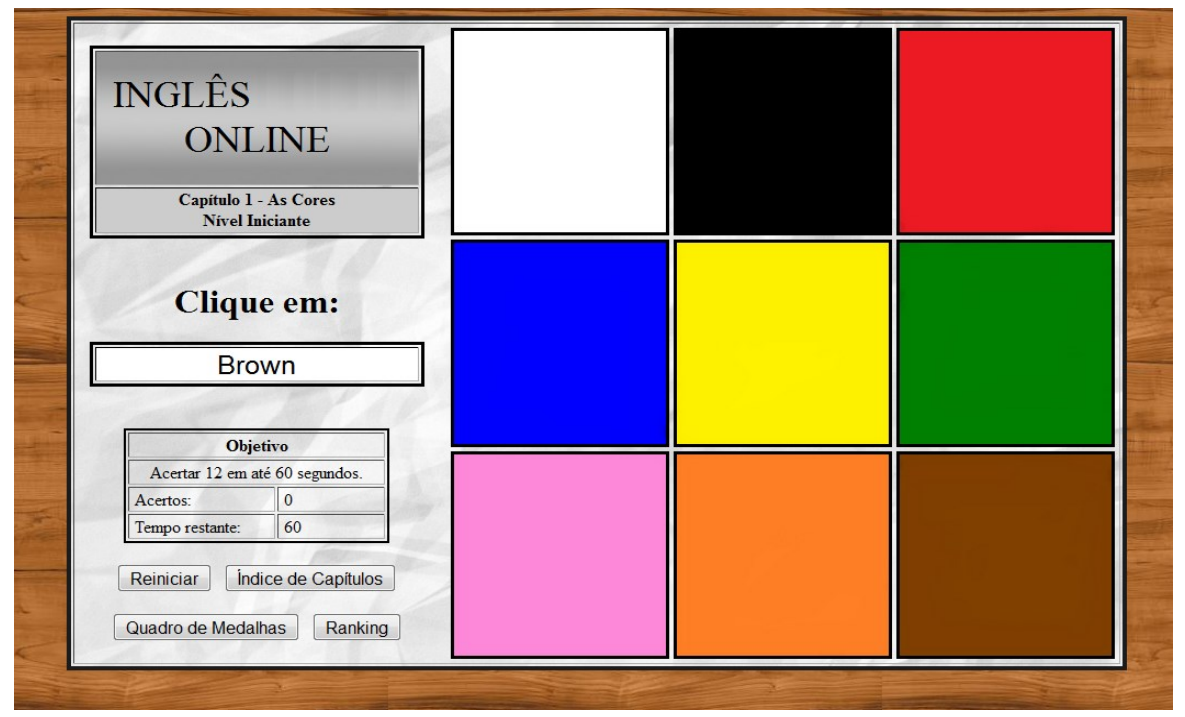

Figura 9-Descontextualização de conteúdo (INLGÊS ONLINE, 2013).

Sobre as questões técnicas, encontramos facilidade de uso, através da existência de instruções claras e objetivas para a utilização do programa e da utilização de linguagem adequada ao público-alvo. Além disso, há robustez e segurança no desenvolvimento do jogo, legibilidade e clareza de layout, e estruturação organizada e hierárquica de seus conteúdos. Da mesma forma, não foram encontrados quaisquer estereótipos ou preconceitos, assim como qualquer outra forma de discriminação ou de violação de direitos.

Apesar de simples, podemos classificá-lo como jogo, por apresentar características como um objetivo - o de acertar doze itens em sessenta segundos -, regras, diversão e o faz de conta. 


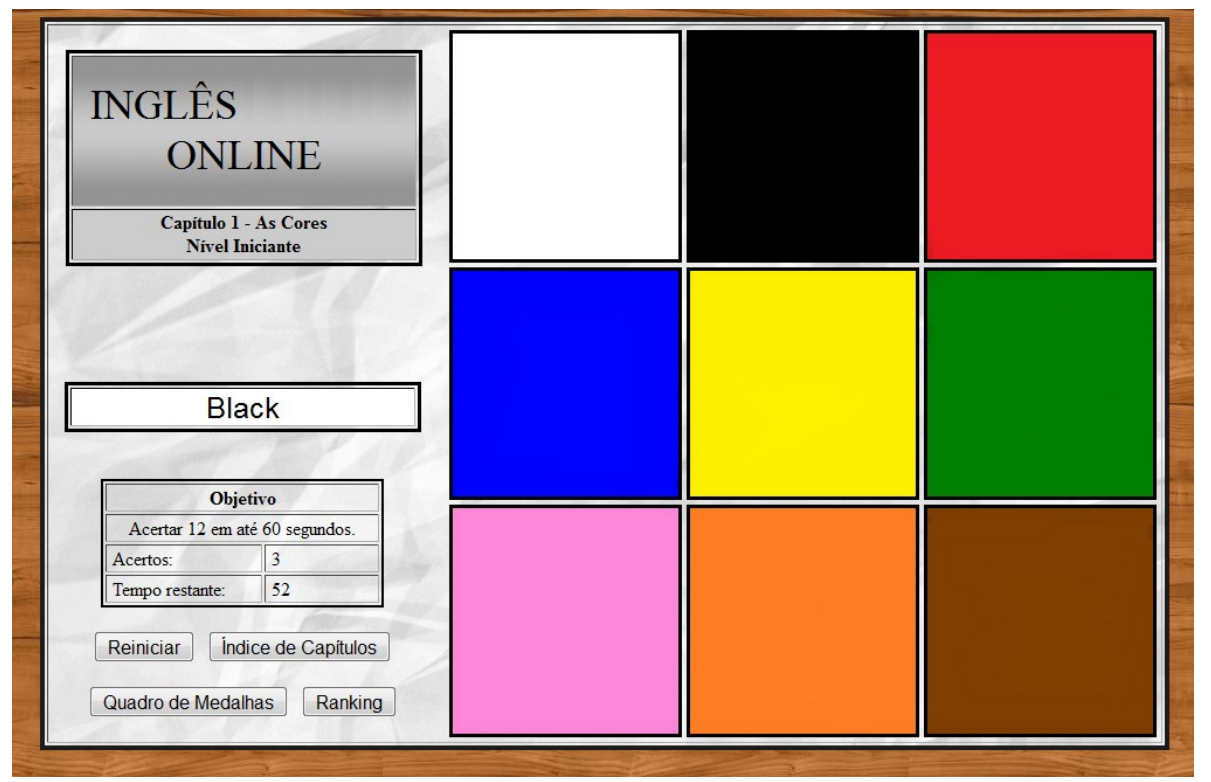

Figura 10 - Objetivo do jogo (INGLÊS ONLINE, 2013)

A diversão e imersão se dão pela corrida contra o tempo para que se cumpra o objetivo. A cada item certo, o quadro do objetivo atualiza o tempo decorrido e o número de acertos. No entanto, essas informações, num momento de imersão, poderiam até passar desapercebidas, devido à sua posição, ao lado do foco de visão do jogador. O tempo restante só é atualizado após o clique na opção escolhida pelo aprendiz. Um código de programação que fizesse com que se mostrasse o tempo correndo independente da interação do jogador seria simples e não implicaria em um software mais pesado ou que afetasse a robustez e segurança do mesmo. Isto evitaria que o aluno passasse do tempo sem perceber e ao clicar na sua resposta viesse apenas a mensagem de que seu tempo acabou, sem que ele tivesse o feedback de se sua resposta estava certa ou errada. 


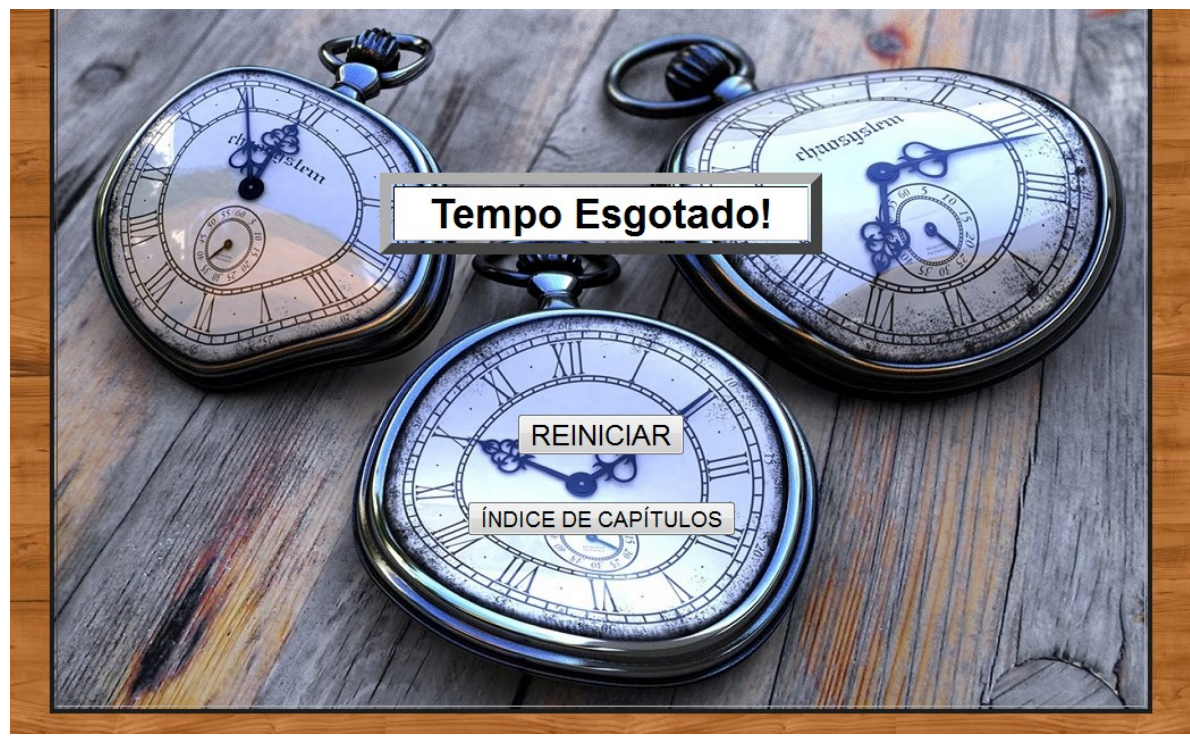

Figura 11 - Tempo esgotado (INGLÊS ONLINE, 2013)

Caso sua resposta esteja errada e ela tenha sido dada dentro do tempo restante, um feedback negativo é dado. Não apenas é dito ao aluno que ele errou, mas também explicado o motivo do seu erro e qual seria a resposta correta. No entanto, a maneira com que isso é feita é antididática em diversos sentidos.

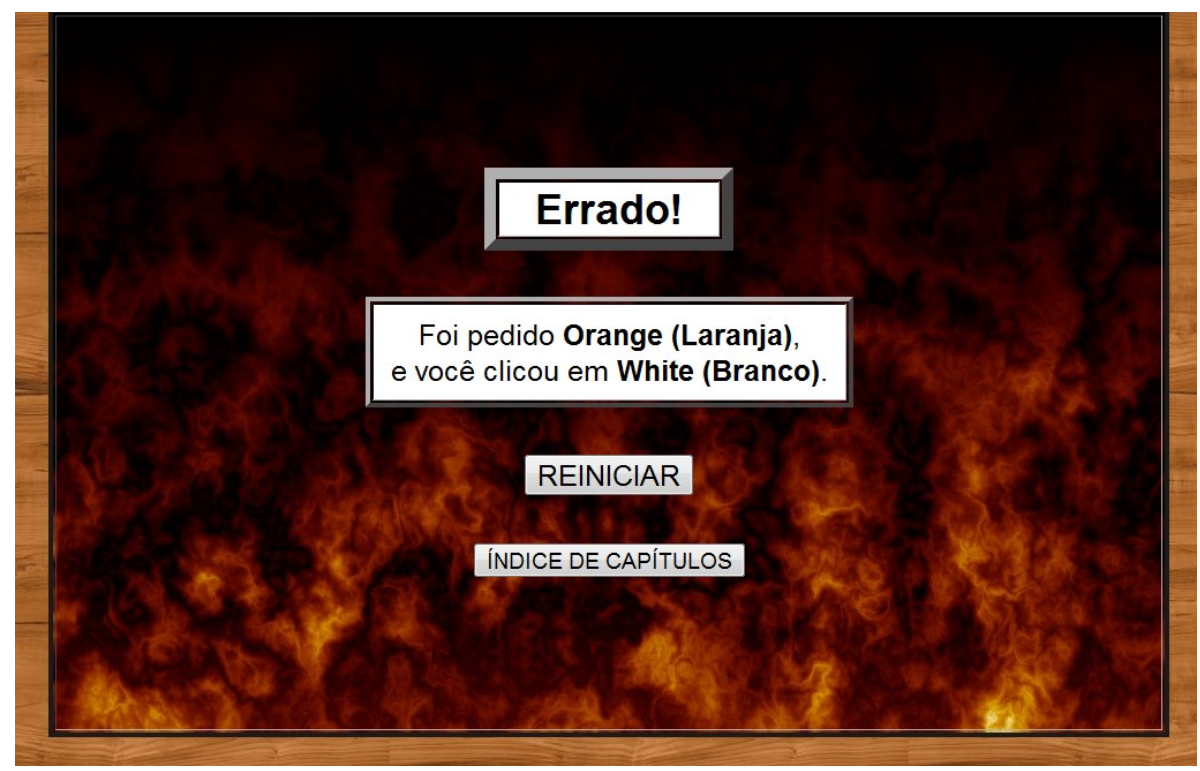

Figura 12 - Feedback negativo (INGLÊS ONLINE)

A informação de erro é dada de forma rude, através da mensagem "Errado!". Também é agressiva a imagem de fundo utilizada para indicar o erro, através das chamas e do escuro, que transmitem uma sensação pesada e desconfortável para o erro, como se 
fosse uma falta grave, e não parte natural do processo de aprendizagem. Mais além, as informações sobre o erro são dadas a partir da tradução do vocábulo pedido e aquele marcado, o que parte, mais uma vez, de uma abordagem formalista que vê a língua apenas como mera tradução da língua materna. Esse problema seria facilmente contornado caso se apresentasse os dois termos na língua alvo, seguidos de imagens das cores que representam.

Caso o jogador consiga alcançar o objetivo do jogo um feedback positivo the é dado.

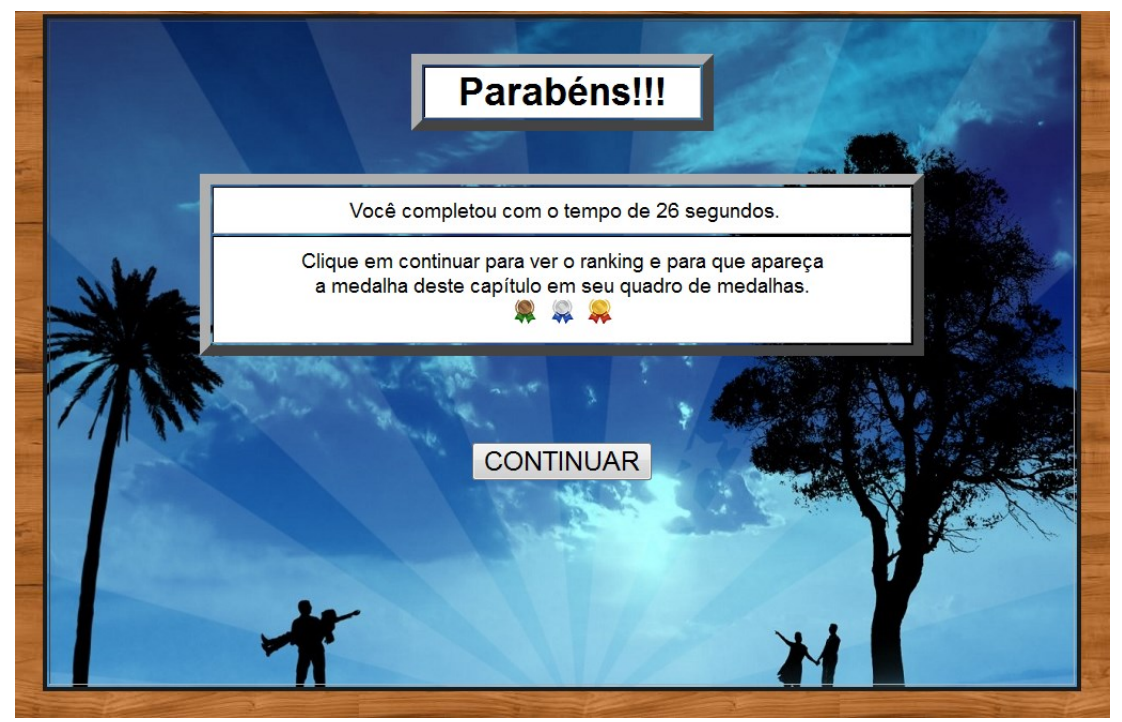

Figura 13 - Feedback positivo (INGLÊS ONLINE)

Este não apenas informa o término da atividade, mas também que o jogador alcançou o objetivo do jogo. Apresenta ainda o tempo utilizado pelo aprendiz e disponibiliza seu resultado em um ranking, o que o motivará não apenas a continuar jogando, como a tentar refazer a fase para alcançar tempos cada vez menores. Mais além, o jogador terá acesso a um ranking próprio, onde poderá verificar seu progresso. A rejogabilidade e a competitividade, características dos jogos de vídeo game bem desenvolvidos, são aqui utilizadas como estímulos ao processo de aprendizagem. Além do mais, a existência de uma memória onde se registre o ponto onde cada usuário estava da última vez que jogou e suas pontuações não só resultam em motivação para continuar jogando, como também em continuidade, em outro momento, do processo de construção do conhecimento.

São encontrados, no entanto, alguns problemas relacionados ao conteúdo linguístico transmitido que podem gerar incorreção no aprendizado e desmotivação. 


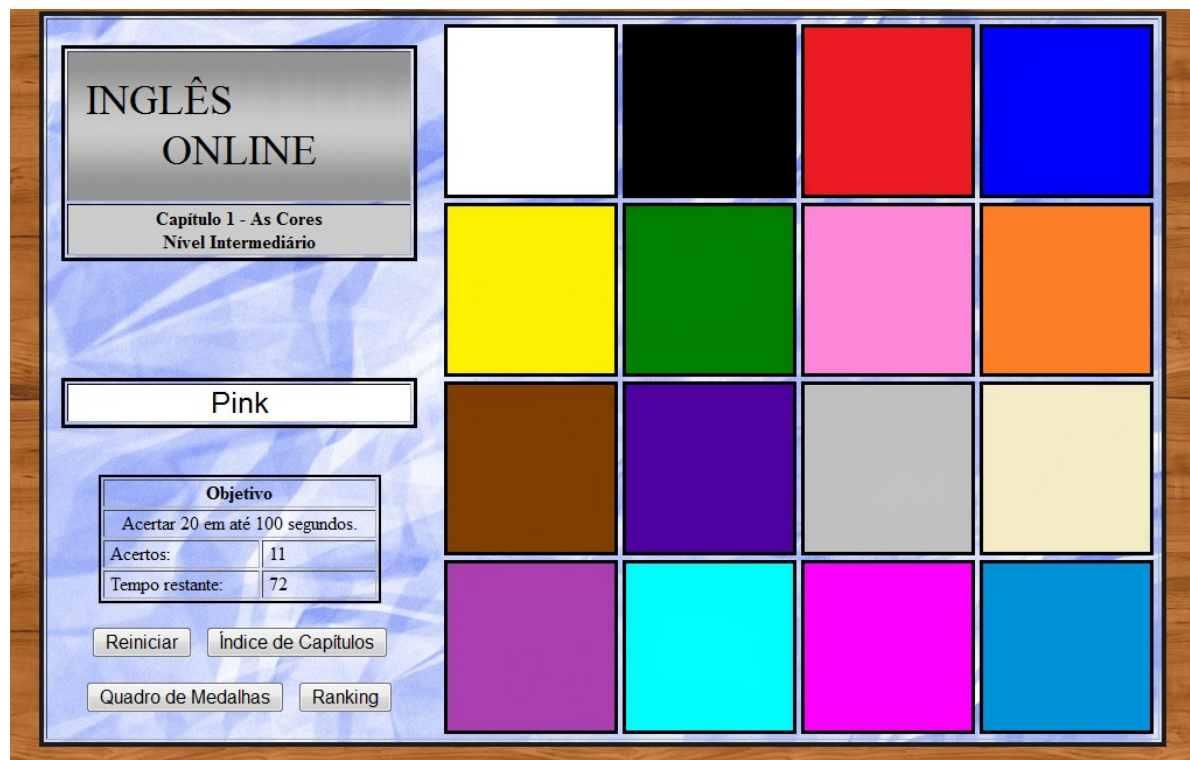

Figura 14 - Apresentação de 'rosa' (INGLÊS ONLINE, 2013)

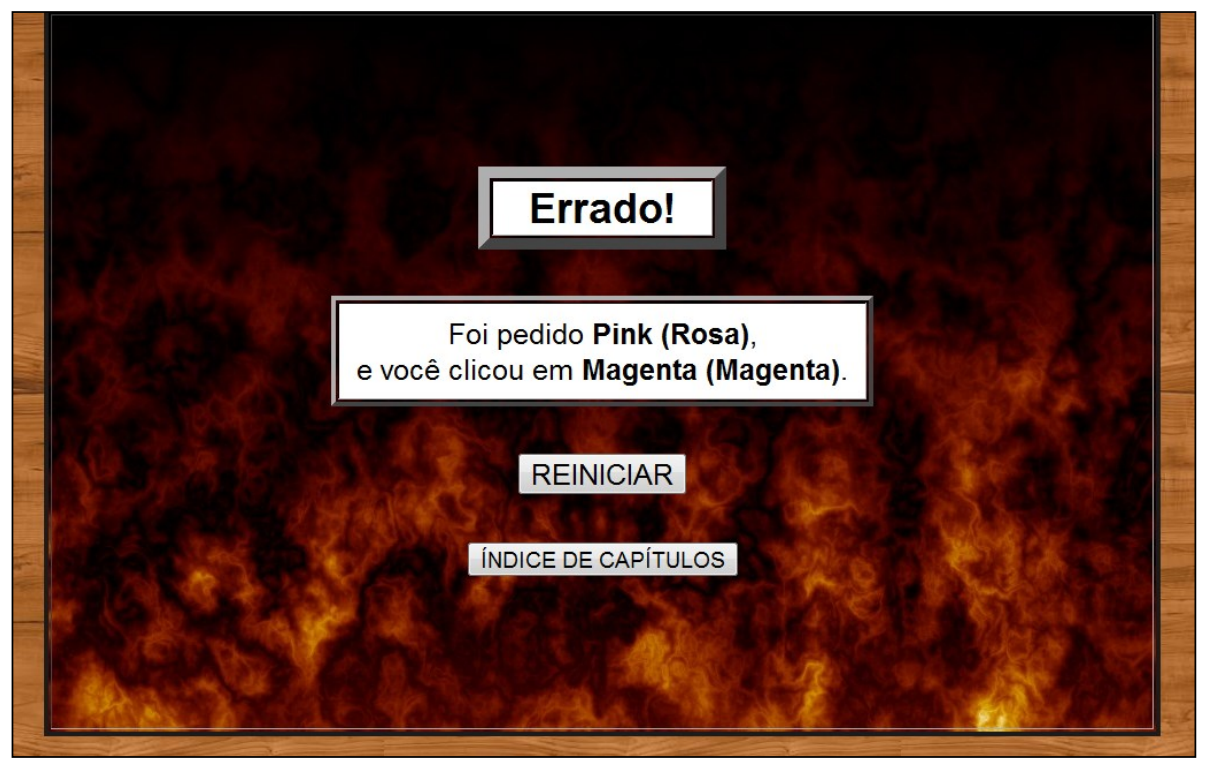

Figura 15 - Feedback negativo 'rosa' x 'magenta' (INGLÊS ONLINE, 2013)

$\mathrm{O}$ primeiro problema encontrado diz respeito às cores trabalhadas. Trabalhar a diferença entre duas cores tão próximas quanto o pink (rosa) e o magenta (magenta), em um jogo que exige o raciocínio rápido, pode facilmente levar o aluno ao erro. Principalmente se levarmos em consideração que, no Brasil, a cor magenta não é comum, sendo o seu tom, frequentemente, definido como rosa. Claro que, sendo essa distinção comum na cultura da língua alvo, deve ser salientada aos aprendizes. Mas seria mais interessante que essa distinção fosse feita em um outro conteúdo multimídia em que o 
aluno pudesse perceber a diferença entre essas cores sem a imposição de tempo para tal, de modo a desenvolver um raciocínio que o levasse a concluir a diferença de uso entre língua materna e língua alvo.

O segundo problema trata das informações fornecidas ao se posicionar o mouse sobre as cores, quando é informado ao jogador o nome da respectiva cor em inglês e em português, eliminando toda a automaticidade e construção de conhecimento através de acerto e erro objetivadas pelo jogo.

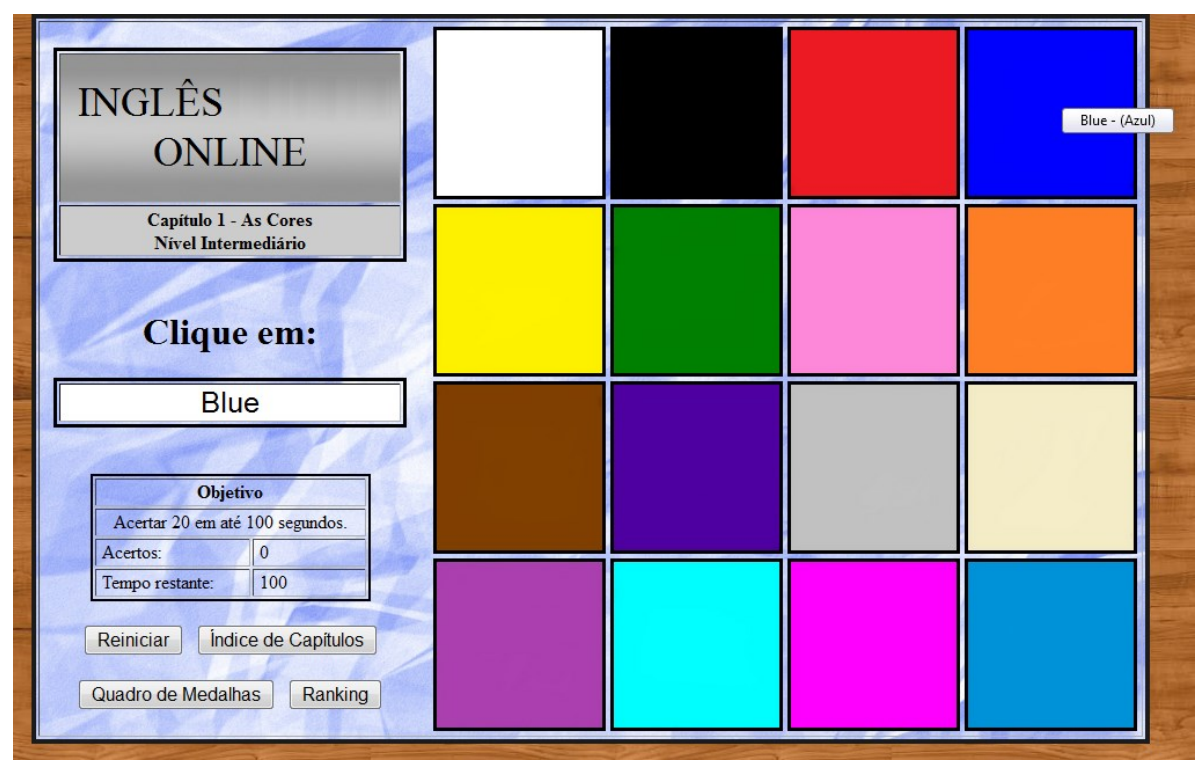

Figura 16 - Texto do cursor para 'azul' (INGLÊS ONLINE, 2013)

Um erro referente ao conteúdo ensinado é encontrado na representação do item lexical navy blue (azul marinho). O tom apresentado como navy blue é o azul claro.

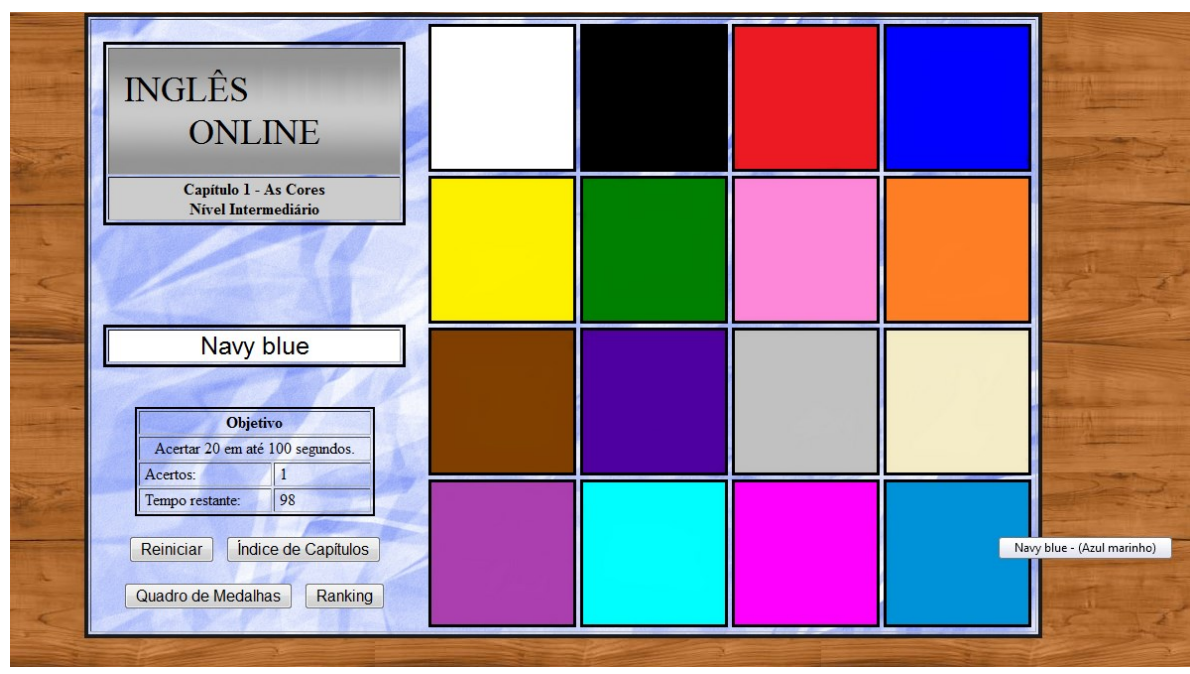

Figura 17 - Texto do cursor para 'azul claro' (INGLÊS OLINE, 2013) 
Mesmo que o aluno não utilizasse a função e respondesse por conta própria, o feedback à sua escolha seria a de que o tom mais claro seria o tom azul marinho. Não se encontra, em nenhum local do software, informações sobre possíveis atualizações por parte dos desenvolvedores, ou contato para que os usuários possam enviar impressões e conteúdos errados para que os desenvolvedores possam corrigir e aperfeiçoar o jogo.

\section{Jogo 3}

O terceiro jogo do corpus de pesquisa possui apresentação gráfica de boa qualidade e elaborada visando seu público alvo.

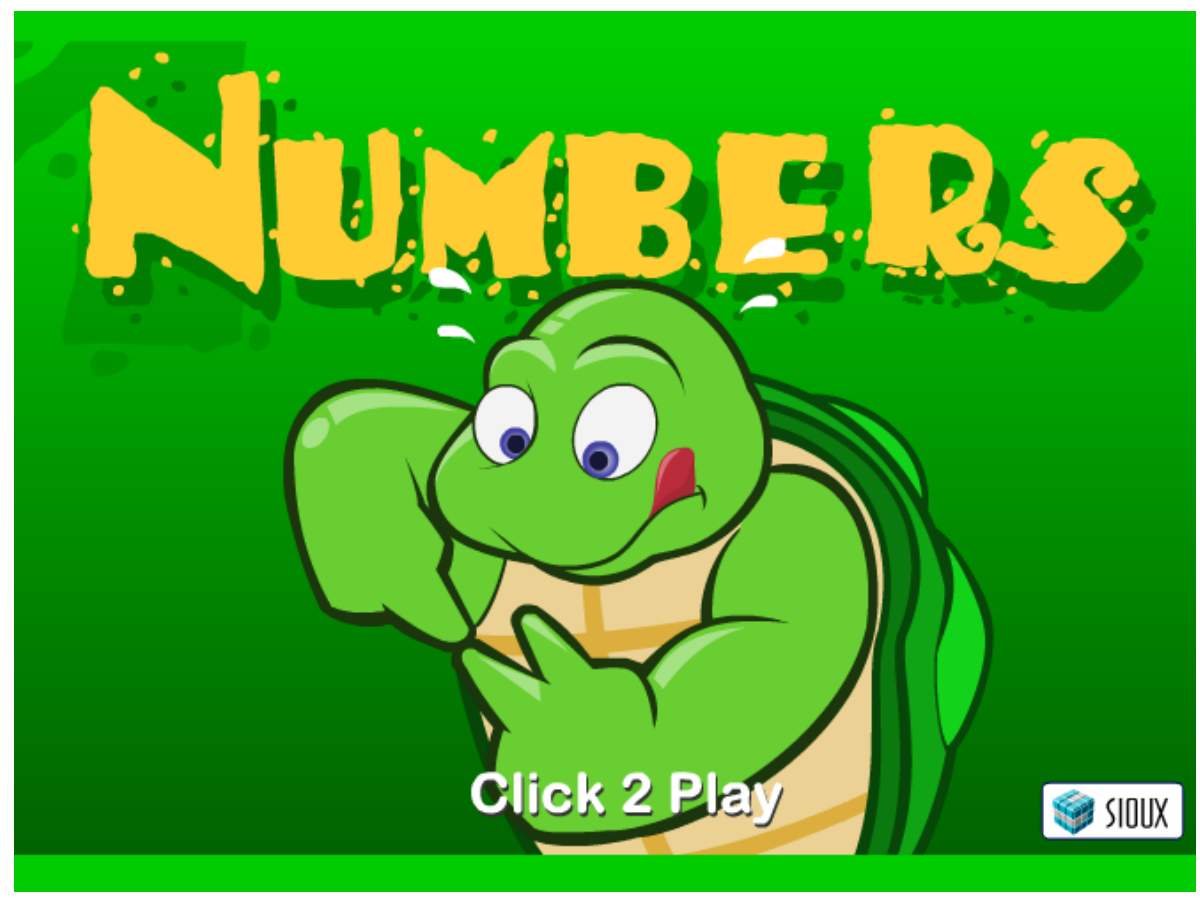

Figura 18 - Apresentação inicial (UOL, 2013)

A sua programação e estruturação é bem elaborada e complexa, facilitando a navegabilidade e utilizando recursos que permitem interatividade maior do que nos jogos anteriores. Ainda assim, não se trata de um programa pesado, o que garante segurança e robustez contra travamentos ou encerramento repentino, e uma boa operacionalidade. $\mathrm{O}$ software pode ser executado em diferentes sistemas operacionais, e sua configuração de hardware mínima necessária para que o programa rode não é exigente.

Sua legibilidade é boa, possuindo clareza quanto à redação de informações e utilizando um bom tamanho e cor de letra. Antes de sua inicialização, possui uma introdução que indica o tópico linguístico trabalhado, e indica como jogar. 


\section{Aprender Inglês}

Você está aqui: Jogos > Jogos Educativos e Infantil > Aprender Inglês

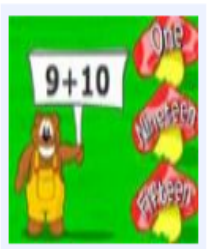

Descrição do Jogo: Divertida corrida de tartarugas que tem como objetivo aprender os números em inglês. Neste jogo de aprender inglês você terá que resolver contas de adição e subtração e dicar no resultado que aparece em inglês. É um jogo educativo muito bacana que testa os conhecimentos em matemática e também em inglês, vale à pena jogar.

Como jogar: Use o mouse para jogar.

Tamanho do Jogo: $75,7 \mathrm{~KB}$

Figura 19 - Introdução (UOL, 2013)

A interdisciplinaridade é presente nessa atividade, onde os alunos deverão desenvolver os cálculos apresentados e clicar na resposta correta dentre as opões de números escritos por extenso em língua inglesa.

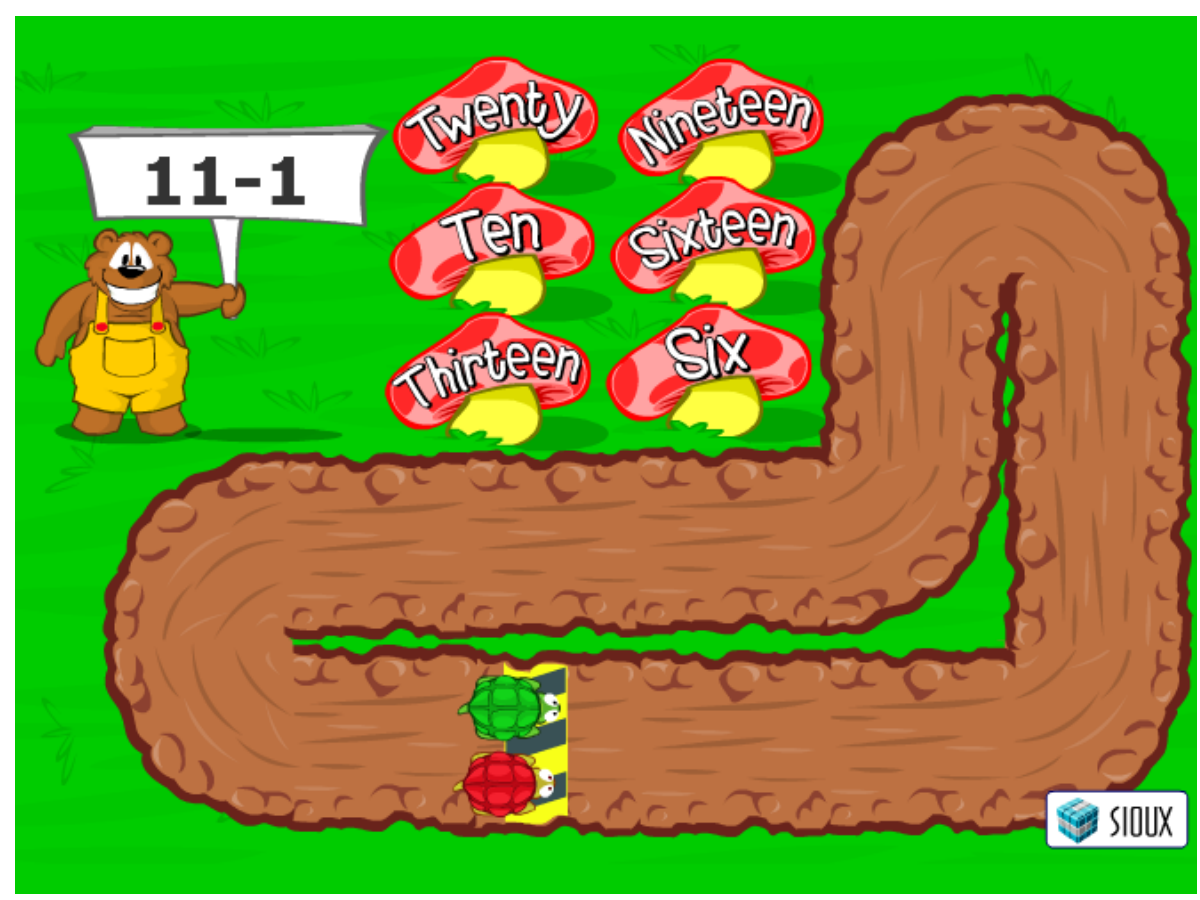

Figura 20 - Interdisciplinaridade (UOL, 2013)

Trata-se de um jogo, uma vez que estão presentes a brincadeira, o objetivo, as regras e o faz de conta. O jogador, representado pela tartaruga verde, anda algumas posições à frente quando dá a resposta correta aos cálculos. O objetivo do jogo é o de se chegar à linha de chegada antes de seu adversário, simulado virtualmente e representado pela tartaruga vermelha, que se desloca quando o jogador erra. 


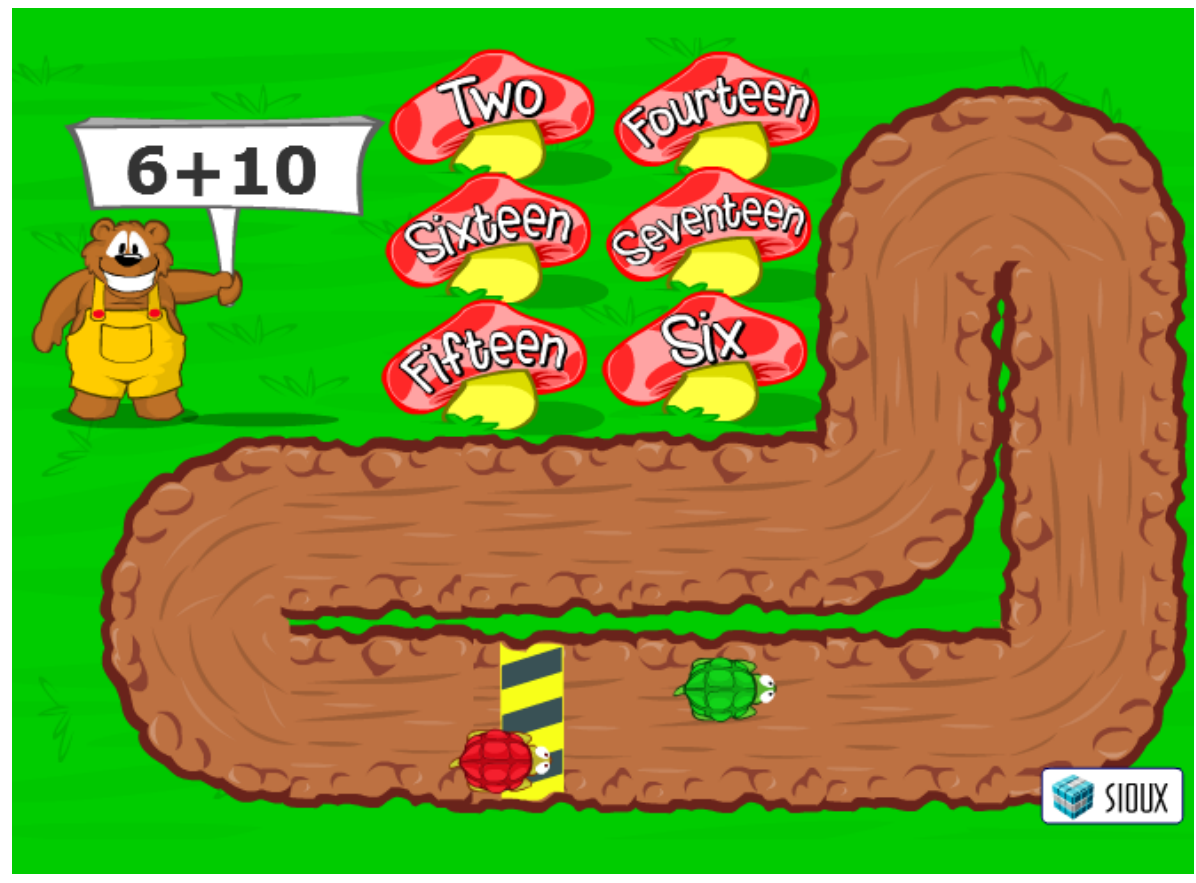

Figura 21 - Vantagem de corrida para acertos e erros (INGLÊS ONLINE, 2013)

Não são apresentadas apenas contas fáceis, de modo que o aluno tenha que desenvolver um raciocínio matemático e não apenas linguístico. Configura assim uma atividade sociointeracional, onde o uso linguístico se dá em um momento genuíno de uso e com vistas à experiência de interação através do uso daquela língua. Ao apresentar o conteúdo através de uma atividade significativa e contextualizada como essa, possibilita-se a sistematização e aprendizagem esquemática do mesmo, levando o aluno à comprovação de hipóteses e relacionamento dos conceitos.

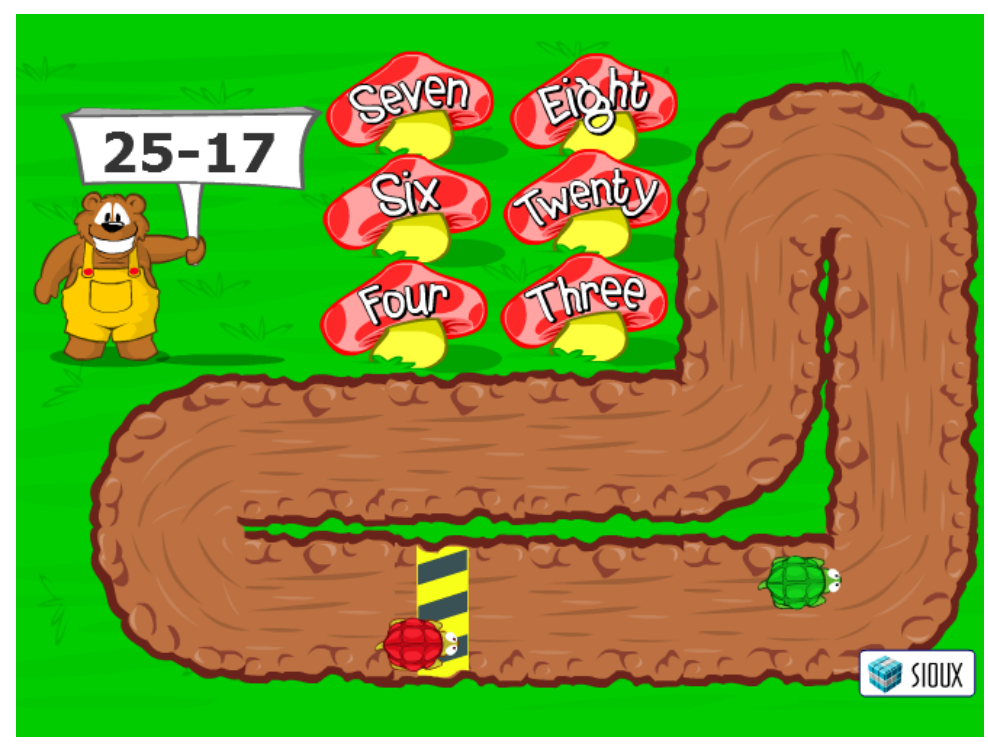

Figura 22- Uso linguístico significativo e contextualizado (UOL, 2013) 
O feedback positivo é dado de forma bem clara e motivadora. Além da locomoção da personagem do jogador, ela demonstra felicidade, o urso que apresenta as contas comemora com pulos, e um som positivo é emitido.

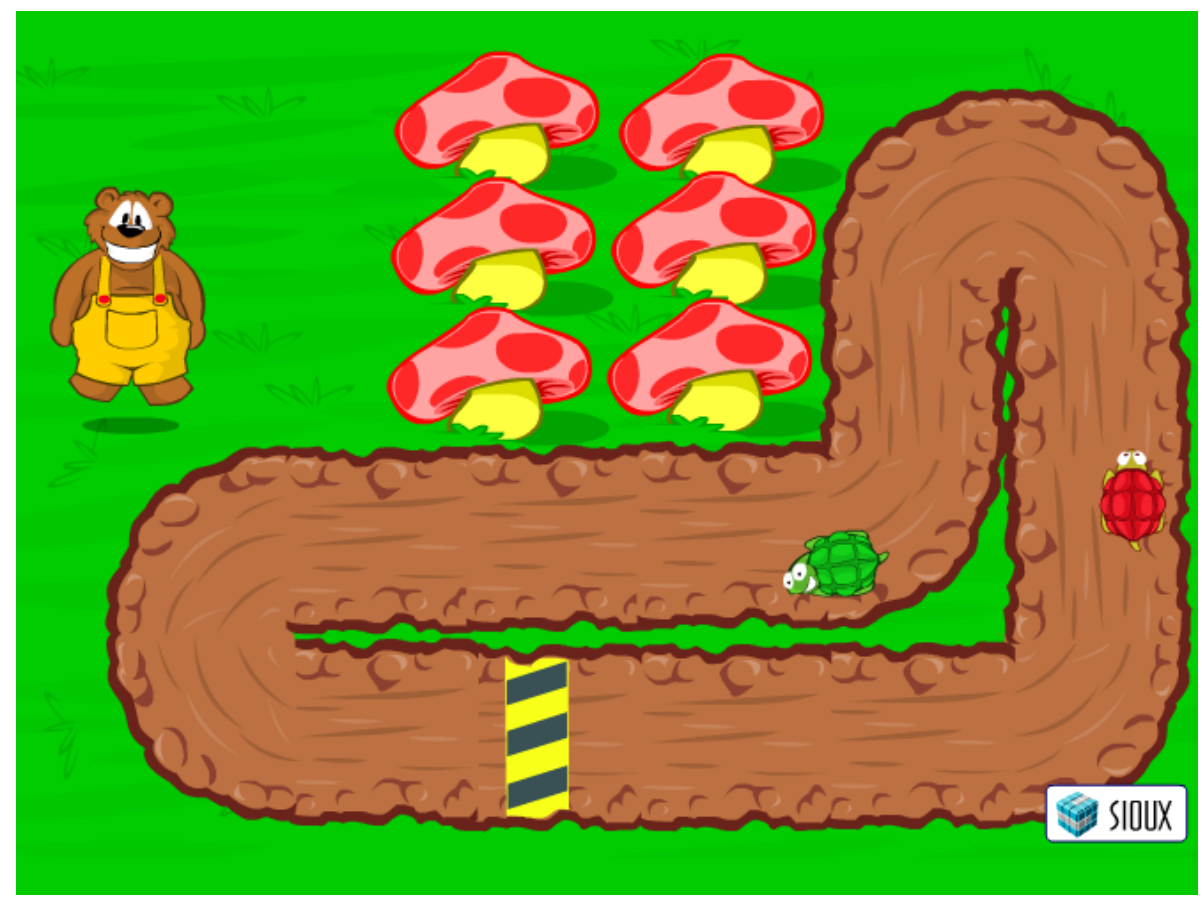

Figura 23 - Feedback positivo (UOL, 2013)

Já o feedback negativo, apesar de bem claro e de utilizar os recursos midiáticos, não é didático. Além da tartaruga adversária avançar, um som de erro é emitido e o urso faz uma cara que demonstra impaciência e decepção, o que representa uma visão do erro como algo negativo. $\mathrm{O}$ aluno que realizar alguns erros pode se sentir desmotivado não apenas em continuar o jogo, como também com a língua e a matemática. Nenhuma indicação da resposta correta é dada, de forma que o momento do erro não pode ser aproveitado como forma de aprendizagem. 


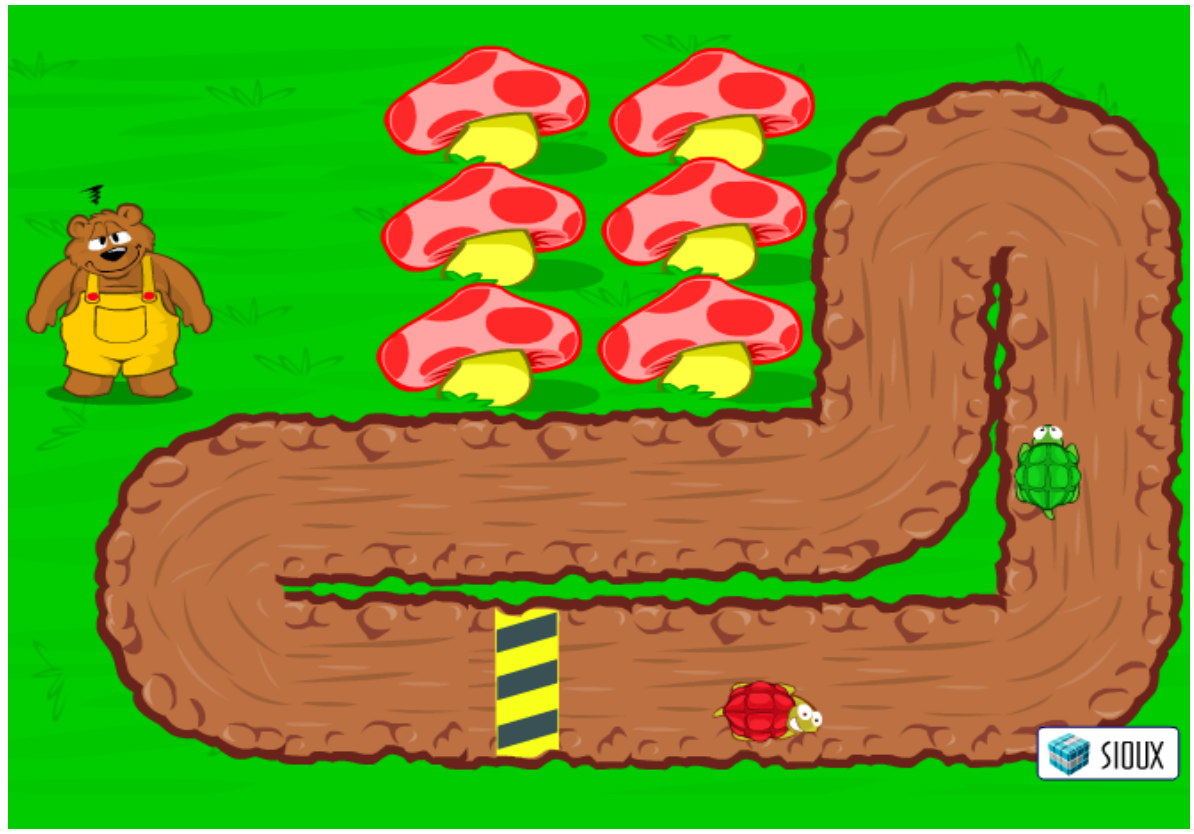

Figura 24 - Feedback negativo (UOL, 2013)

Ao se vencer, um feedback final é dado onde o urso vem à frente da tela dar os parabéns ao jogador. Este não apenas confirma ao aprendiz que ele concluiu seu objetivo, como também o motiva a continuar jogando. Além disso, a maneira como é dado mantém o uso da língua inglesa, de forma que a interação continua a se dar na língua alvo. Neste caso, o feedback ainda cumpre a função de levar um novo vocábulo na língua ao conhecimento do aluno.

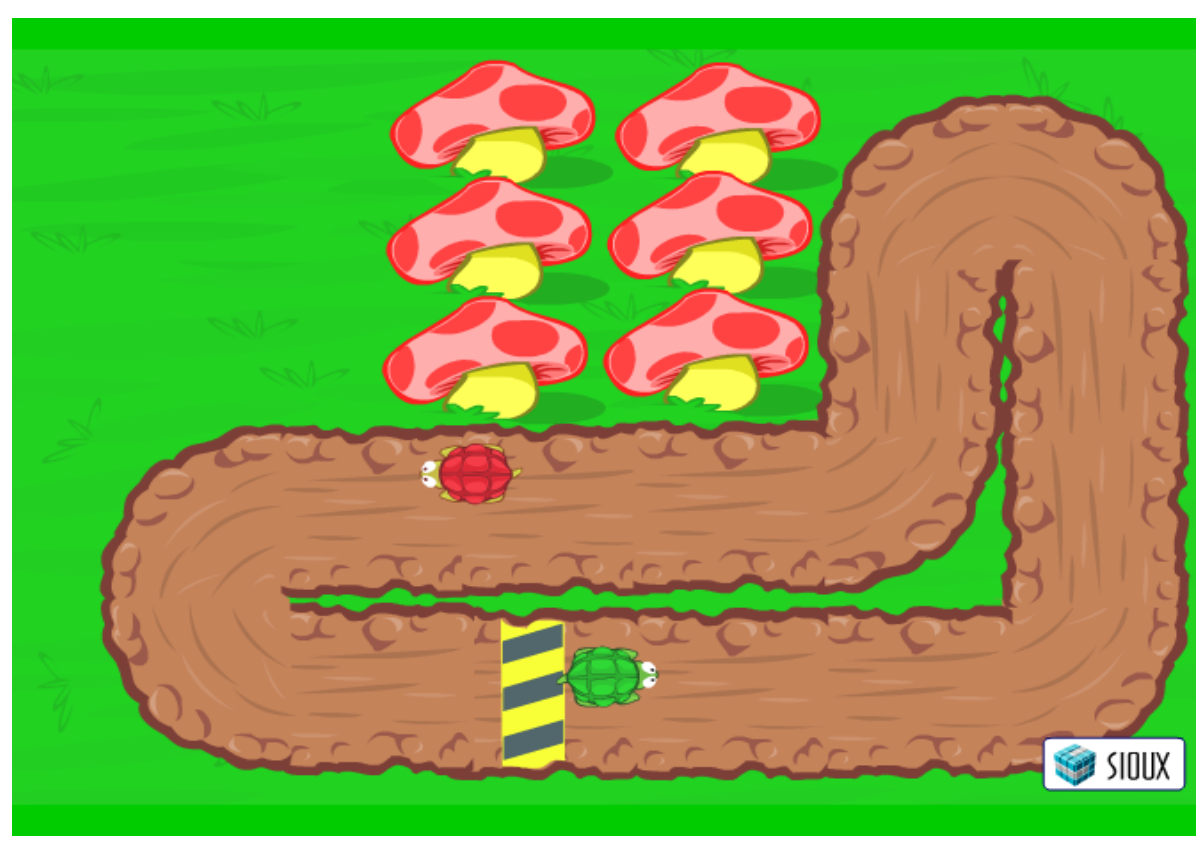

Figura 25 - Feedback final com cruzamento da linha de chegada (UOL, 2013) 


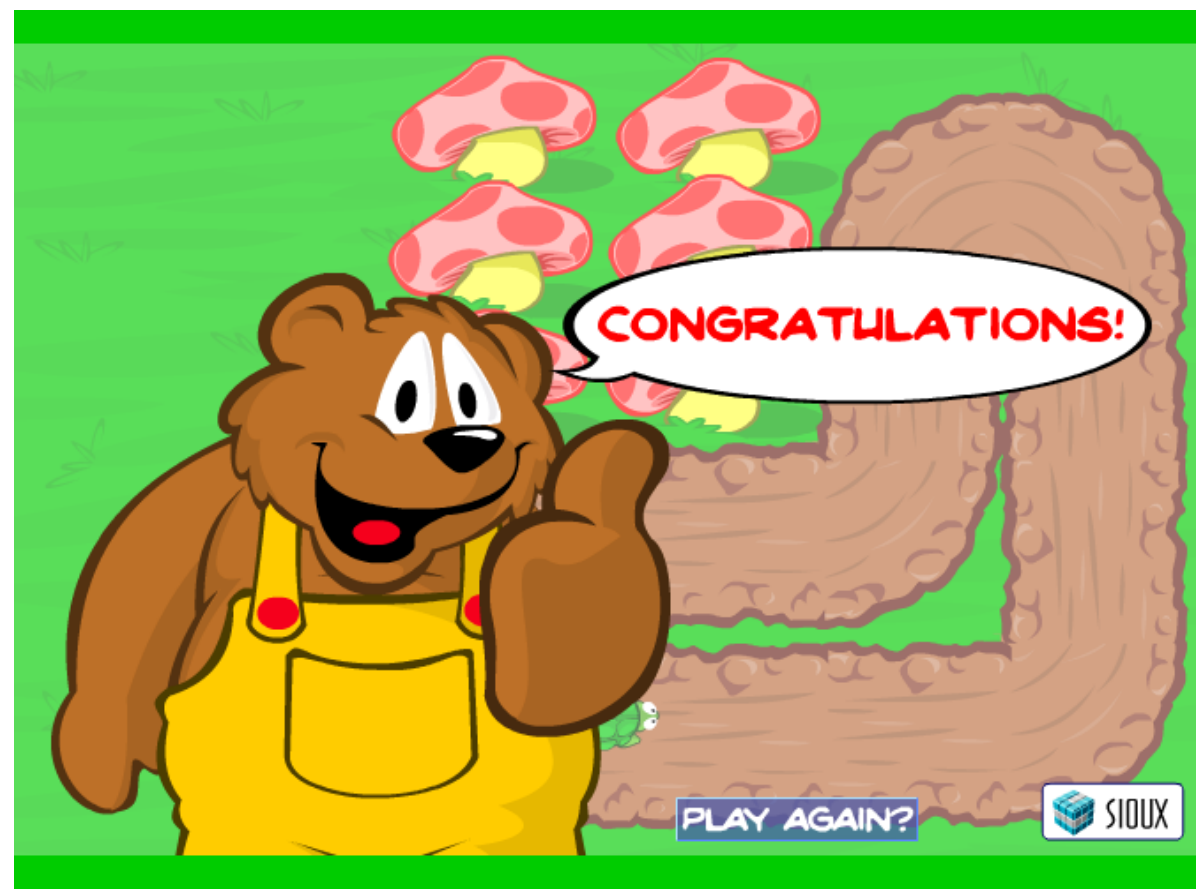

Figura 26 - Feedback final com parabenização na língua alvo (UOL, 2013)

Apesar deste jogo possuir características que o põem à frente dos anteriores, outras levam a problemas que podem atrapalhar seu uso ou dificultar o processo de ensinoaprendizagem. Primeiramente, destaca-se o fato de que não há instruções claras sobre o que deve ser feito. Além disso, não acompanha o jogo nenhum guia de ajuda ou manual de instruções, de forma que o professor deve jogar o jogo e testar todas as suas possibilidades previamente. Acrescenta-se a isso, o fato de que não há forma de contato com os desenvolvedores para opiniões e sugestões. Ainda, não há como salvar o jogo para que seja retomado mais tarde do ponto onde se parou. Caso o aluno interrompa a partida por algum motivo, terá que recomeçá-la do zero mais tarde. Assim, todo o processo desenvolvido até ali é perdido.

\section{CONSIDERAÇÕES}

Esse trabalho teve por objetivo apresentar procedimentos para avaliação de jogos presentes em softwares educacionais para o ensino de inglês como língua estrangeira. No que diz respeito às perguntas de pesquisa aqui propostas pudemos concluir, primeiramente, que, dos três jogos avaliados, apenas o segundo e o terceiro apresentam características lúdicas que os definiriam como de fato pertencentes ao gênero jogo. $\mathrm{O}$ primeiro jogo, por 
sua vez, representa apenas um exercício de prática formalista, que poderia ser facilmente encontrado sob a forma impressa, apenas reproduzida no meio virtual. Dessa forma, houve, no primeiro, uma simples transferência de suporte, sem que sequer fossem aproveitados os diversos recursos que um conteúdo multimídia pode oferecer.

Sobre a questão de inserirem-se em na proposta didático-pedagógica que indicam, nenhuma das três atividades puderam ser avaliadas, uma vez que não indicam qual proposta defendem ou mesmo qual a metodologia ou abordagem que utilizam. A falta de indicação de tais informações é uma falta grave, uma vez que impede que o professor ou profissional responsável pela aquisição de materiais didáticos para o colégio possa, antes de adquiri-lo, averiguar se o mesmo está de acordo com as políticas e teorias elegidas pela equipe de professores daquela disciplina e pedagogos da instituição como adequadas para os conteúdos que se pretende ensinar e para seu público discente.

Buscamos verificar também se os três conteúdos multimídia estavam em consonância como o que determinam os documentos oficiais que regulam o ensino de inglês como língua estrangeira no Brasil. Dentre os três programas avaliados, apenas o terceiro parece ser compatível com o explicitado por essas legislações. Os outros dois não chegam a desviarem-se por completo dos documentos reguladores brasileiros, mas destoam em alguns momentos do que é ali exposto, principalmente a primeira atividade avaliada.

Finalmente, pretendemos observar se os três componentes de nosso corpus seriam aprovados pelas questões avaliadoras referentes aos jogos apresentados em conteúdos multimídia do Edital PNLD 2014. O primeiro conteúdo seria rapidamente descartado pelos avaliadores do programa, por ir contra grande parte das questões propostas. O segundo jogo parece estar de acordo com as especificações técnicas e critérios de avaliação de conteúdo multimídia expostas pela avaliação do Edital; no entanto, divergia, em muitos pontos, das seções de critérios eliminatórios específicos da área de línguas estrangeiras modernas. Já o terceiro jogo cumpre com a maior parte dos requisitos impostos pelo Edital PNLD, mas ainda sim peca em alguns poucos. Como o descumprimento de quaisquer requisitos do processo de seleção do PNLD implica em desqualificação do material, por esses poucos problemas, esse software também seria recusado.

Podemos concluir, portanto, que caberá ao professor ou à equipe de professores decidir quais critérios são essenciais e quais são adicionais interessantes mas não indispensáveis. Não objetivamos no presente trabalho determinar quais as questões de avaliação que devem ser adotadas por todos os professores em quaisquer contextos 
educacionais e corpos discentes. Visamos apenas apresentar questões que parecem ser interessantes para nortear uma avaliação. E principalmente demonstrar que o processo de seleção de um jogo educativo, assim como o de qualquer material didático deve pautar-se em critérios e referências teóricas, técnicas e legais.

Assim sendo, o professor não deve ter medo de reprovar todas as opções de jogos educativos se necessário. Em primeiro lugar porque de nada adiantará adotar uma opção que não cubra os requisitos necessários, ou que não esteja de acordo com a abordagem pedagógica e metodológica que se pretende seguir. Adotar um software educacional ou determinados jogos educativos apenas para inserir a aula no mundo tecnológico, mas de forma retrógrada no que tange a questões didáticas, pedagógicas e metodológicas é um desserviço que se faz ao aluno, ao colégio e ao ensino. Em segundo lugar porque apenas a partir de suas reprovações que as editoras de coleções pedagógicas acompanhadas por softwares ou mesmo empresas de programação e desenvolvimento de softwares educacionais irão aprimorar a qualidade dos produtos que dispõem ao mercado de ensinoaprendizagem de línguas. Comparativamente, assim como é através do erro que o aluno cria experiências de aprendizado significativas, é através das reprovações ou baixas vendas que essas empresas descobrirão o que tornará seus jogos educativos mais adequados.

Acima de tudo, podemos concluir com o presente trabalho que há uma real necessidade de uma integração de conhecimentos entre profissionais especializados na área tecnológica e aqueles especializados na área de ensino de línguas para que os jogos educativos sejam desenvolvidos de maneira interdisciplinar e agregando conhecimentos de ambas as áreas. Desse modo, o resultado final será de fato um jogo, desenvolvido de maneira eficiente e com um alto grau de usabilidade, e garantir-se-á que realmente seja educacional, promovendo assim um real ganho no desenvolvimento da aprendizagem de língua.

\section{REFERÊNCIAS}

ADAMS, Ernest. Fundamentals of Game Design. Second Edition. Upper Saddle River: Pearson Prentice Hall, 2010.

BERTOLDI, S. Avaliação de software educacional: Impressões e Reflexões. Trabalho de conclusão de curso bacharel em Ciência da Computação da Universidade Federal de Santa Catarina. Santa Catarina: 1999. 
BRASIL, SEF/MEC. Parâmetros Curriculares Nacionais: terceiro e quarto ciclos do ensino fundamental: língua estrangeira. Secretaria de Educação Fundamental. Brasília:MEC/SEF, 1998.

BRASIL. Edital de Convocação para o Processo de Inscrição e Avaliação das Coleções Didáticas para o Programa Nacional do Livro Didático (PNLD) 2014. Brasília: Ministério da Educação, Secretaria de Educação Básica, 2012.

BRASIL. Guia de Livros Didáticos: PNLD 2014: Língua Estrangeira Moderna - Anos Finais do Ensino Fundamental. Brasília: Ministério da Educação, Secretaria de Educação Básica, 2013.

HAYS, R.T. The Effectiveness of Instructional Games: A Literature Review and Discussion. Orlando: Naval Air Warfare Center Training System Division, 2005.

INGLES ONLINE. Fase 1 - As Cores. 2013. Disponível em: $<\underline{\text { http: } / / w w w . i n g l e s g}$ ratisonline.com.br/> Acesso em 25 de abril de 2016.

LEÃO, L. B. C. Vídeo games de RPG e a aquisição lexical multimodal de inglês como língua estrangeira. Dissertação de Mestrado em Estudos de Linguagem. Niterói, RJ: Instituto de Letras, UFF, 2014.

LYSTER, R. \& RANTA, L. Corrective Feedback and Learner's Uptake. In: Studies in Second Language Acquisition, 19/1. 37-61, 2007.

MANY THINGS. Adjectives. 1997. Disponível em: < http://www.manythings.org/vq/mcadj.html $>$. Acesso em 25 de abril de 2016.

MORAIS, R. X. T. Software educacional: A importância de sua avaliação e do seu uso nas salas de aula. Trabalho de conclusão de curso em Bacharel em Ciência da Computação da Faculdade Lourenço Filho. Fortaleza: 2003.

PRENSKY, Mark. Digital game-based learning. New York: McGraw-Hill, 2001.

SILVA, R. J. S. Avaliação de Software Educacional: critérios para definição da qualidade do produto. In: Anais de congresso do III Simpósio Nacional ABCiber da ESPM/SP. São Paulo: 2009.

UOL. Aprender Inglês. 2013. Disponível em: $<$ http://jogosonlinegratis.uol.com.br/jogoonli ne/aprender-ingles/>. Acesso em 25 de abril de 2016.

\section{A AUTORA}

Luciana Braga Carneiro Leão Junqueira é mestre em Estudos de Linguagem pela Universidade Federal Fluminense e doutoranda em Linguística pela Universidade do Estado do Rio de Janeiro. Sua área de interesse engloba ensino e aprendizagem de línguas estrangeiras, multimodalidade, aquisição incidental de léxico, aprendizagem através de jogos eletrônicos, ensino de inglês para fins específicos, Linguística Aplicada, Linguística 
Cognitiva, novas tecnologias de informação e comunicação (NTICs) e gamificação. Atua como professora efetiva I de língua inglesa da Fundação de Apoio à Escola Técnica (FAETEC).

E-mail: lucianabclj@gmail.com 